\title{
Heart Valve Tissue Engineering: Concepts, Approaches, Progress, and Challenges
}

\author{
KAREN MENDELSON and FREDERICK J. SCHOEN \\ Department of Pathology, Brigham and Women's Hospital and Harvard Medical School, Boston, MA
}

(Received 6 February 2006; accepted 11 July 2006; published online: 12 October 2006)

\begin{abstract}
Potential applications of tissue engineering in regenerative medicine range from structural tissues to organs with complex function. This review focuses on the engineering of heart valve tissue, a goal which involves a unique combination of biological, engineering, and technological hurdles. We emphasize basic concepts, approaches and methods, progress made, and remaining challenges. To provide a framework for understanding the enabling scientific principles, we first examine the elements and features of normal heart valve functional structure, biomechanics, development, maturation, remodeling, and response to injury. Following a discussion of the fundamental principles of tissue engineering applicable to heart valves, we examine three approaches to achieving the goal of an engineered tissue heart valve: (1) cell seeding of biodegradable synthetic scaffolds, (2) cell seeding of processed tissue scaffolds, and (3) in-vivo repopulation by circulating endogenous cells of implanted substrates without prior in-vitro cell seeding. Lastly, we analyze challenges to the field and suggest future directions for both preclinical and translational (clinical) studies that will be needed to address key regulatory issues for safety and efficacy of the application of tissue engineering and regenerative approaches to heart valves. Although modest progress has been made toward the goal of a clinically useful tissue engineered heart valve, further success and ultimate human benefit will be dependent upon advances in biodegradable polymers and other scaffolds, cellular manipulation, strategies for rebuilding the extracellular matrix, and techniques to characterize and potentially non-invasively assess the speed and quality of tissue healing and remodeling.
\end{abstract}

Keywords-Heart valve remodeling, Engineered tissue heart valves, Biodegradable scaffold, Decellularized scaffold, Circulating stem cells.

\section{INTRODUCTION}

Potential applications of tissue engineering in regenerative medicine range from structural tissues (e.g., skin, cartilage, bone) to complex organs (e.g., heart and other components of the cardiovascular system, liver, kidney, pancreas). In each case, there are limitations to conventional surgical approaches and existing prosthetic devices, serious complications associated with transplantation, and

Address correspondence to Frederick J. Schoen, Department of Pathology, Brigham and Women's Hospital, 75 Francis Street, Boston, MA 02115. Electronic mail: fschoen@partners.org critical shortages of available donor tissues. Cardiovascular tissue engineering has primarily considered blood vessels, ${ }^{58,102,103,104,114,178}$ myocardium, ${ }^{27,36,74,80,123}$ and heart valves. ${ }^{14,119,122,176}$ This review focuses on the application of tissue engineering technology to heart valves.

Currently, adults who undergo replacement of diseased valves by either mechanical prosthetic or tissue valves (including bioprosthetic valves [porcine aortic valve or bovine pericardial xenograft], cadaveric allograft, or pulmonaryto-aortic autograft valves [Ross procedure]) generally have enhanced survival and quality of life. ${ }^{127}$ Nevertheless, each of these valve types has its limitations-in particular, mechanical valves require anticoagulation to control thromboembolism, while bioprosthetic and allograft valves frequently undergo calcification and structural deterioration. ${ }^{50,64,146}$

Advantages of an engineered tissue heart valve would likely include nonthrombogenicity, infection resistance, and cellular viability. The design criteria and characteristics for conventional and tissue engineered replacement heart valves are summarized and compared in Table 1 . The most immediate need for heart valve tissue engineering and regeneration technology is in the pediatric and young adult population in which the results of valve replacement are not as favorable as those in older adults. ${ }^{35,68}$ Most exciting is the possibility of growth, repair, and remodeling as a child recipient matures, thus eliminating the repetitive surgeries typically necessitated by the inability of a valve substitute to enlarge as an individual grows. Only autografts (such as Ross valves transplanted from the pulmonary-to-aortic position in an individual) presently are viable, ${ }^{120}$ but the Ross procedure is technically difficult, risky, only serves a small patient subset, and has controversial results, including uncertainty over whether the grafts will grow commensurate with recipient growth. ${ }^{67}$

The goal to engineer functional heart valve tissue presents a unique combination of challenges. Normal heart valves are vital and dynamic tissues composed of specialized cells and extracellular matrix (ECM) that respond and remodel in response to changes in local mechanical forces. ${ }^{121,143}$ Approximately 40 million times a year, 
TABLE 1. Design objectives for and characteristics of replacement heart valves.

\begin{tabular}{|c|c|c|}
\hline Feature to optimize & Conventional (Mechanical, bioprosthetic) & Tissue engineered \\
\hline Closure of leaflets & Rapid and complete & Rapid and complete \\
\hline Size of orifice area & Less than that of natural valves & Better \\
\hline $\begin{array}{c}\text { Mechanical } \\
\text { properties }\end{array}$ & Stable & Stable \\
\hline Surgical insertion & Easy and permanent & Easy and permanent \\
\hline Risk of thrombosis & $\begin{array}{l}\text { Yes, especially mechanical valves, which require } \\
\text { anticoagulation, causing vulnerability to hemorrhage }\end{array}$ & No; endothelial surface to inhibit thrombogenesis \\
\hline \multirow[t]{2}{*}{$\begin{array}{l}\text { Risk of structural } \\
\text { dysfunction }\end{array}$} & $\begin{array}{l}\text { Degradation of synthetic materials rare with mechanical } \\
\text { valves }\end{array}$ & Resistant to degradation and calcification \\
\hline & $\begin{array}{l}\text { Tissue degradation and calcification of leaflets with } \\
\text { bioprosthetic valves }\end{array}$ & \\
\hline Risk of Infection & Ever present & Resistant to infection \\
\hline Viability & No & $\begin{array}{l}\text { Yes, able to repair injury, remodel, and potentially } \\
\text { grow with patient }\end{array}$ \\
\hline
\end{tabular}

opening and closing of the leaflets induces repetitive changes in the shape, dimensions, and stress of the leaflets and supporting valvular structures (Fig. 1). ${ }^{147}$ A successful tissue engineered valve and its components must not only accommodate those deformations but also have ongoing strength, flexibility, and durability, beginning at the instant of implantation and continuing indefinitely thereafter, possibly despite an evolving tissue architecture.

This review provides a contemporary analysis of heart valve tissue engineering and regeneration, emphasizing the evolving understanding of heart valve biology, the promise and difficulties demonstrated by in-vivo studies done to date, and the critical challenges that will be encountered in translating the potential of this exciting therapeutic modality from the laboratory to the clinical realm. To put the technology and the evolving enabling science into context, we begin by examining the complex and dynamic structural components that are needed to accomplish normal heart valve function, biomechanics, physiological tissue maintenance, homeostasis, and ongoing health. Our discussion of the basic principles of tissue engineering summarizes current principles of scaffolding and cell sourcing. Subsequently, we examine three potential approaches to the field of tissue-engineered heart valves: (1) cell seeding of biodegradable synthetic scaffolds, (2) cell seeding of processed tissue scaffolds, and (3) in-vivo repopulation by circulating endogenous cells of implanted substrates without prior in-vitro cell seeding. Finally, we analyze challenges to the field and suggest future directions for both preclinical and translational (clinical) studies that will be needed to address key regulatory issues for safety and efficacy of the application of tissue engineering and regenerative approaches to heart valves. Our primary goal is to stimulate thinking in the field by introducing concepts such as outcome criteria, biomarkers, molecular imaging, product release criteria, questions raised by the integration of engineered heart valves with the host tissues, and uncertain- ties engendered by patient-to-patient heterogeneity in key biological processes such as tissue remodeling capability. Our discussion in this paper underscores that the development and application of innovative approaches to repair and regenerate damaged or diseased heart valves requires the integration of numerous biological, engineering, and technological principles.

\section{HEART VALVE FUNCTION AND STRUCTURE}

Healthy native heart valves maintain unidirectional blood flow via an extraordinarily dynamic functional structure with several key characteristics: viability, sufficient strength to withstand repetitive and substantial mechanical stress, and ability to adapt and repair injury by connective tissue remodeling. A rational approach to heart valve tissue engineering depends on a thorough understanding of the complex normal functional elements and their coordinated interactions (Table 2). ${ }^{185}$ For the trileaflet semilunar valves (aortic and pulmonary), the important structures are the cusps (which avoid prolapse by substantial coaptation), the commissures, and the supporting structures in the aortic and pulmonary roots. For the atrioventricular valves (mitral and tricuspid), the key components are the leaflets, commissures, annulus, chordae tendineae, papillary muscles, and atrial and ventricular myocardium. Valve leaflets and cusps have few and only focal blood vessels (vessels may be present in the proximal portion near the myocardium), likely because valves cusps and leaflets are sufficiently thin to be nourished predominantly by diffusion from the heart's blood. Valve leaflets and cusps also have nerves, but their significance is uncertain. ${ }^{87}$

The four cardiac valves have microstructural similarities; however, the aortic valve best illustrates the essential features and serves as a paradigm for microstructural and cellular adaptation to functional requirements. The aortic valve is the most frequently diseased and also commonly 
(a)

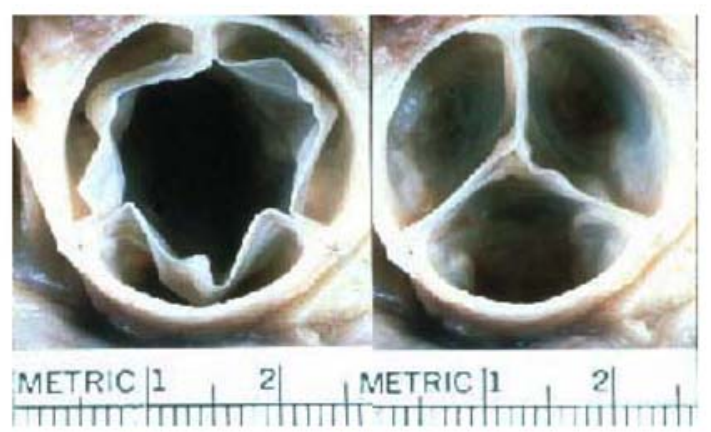

(c)

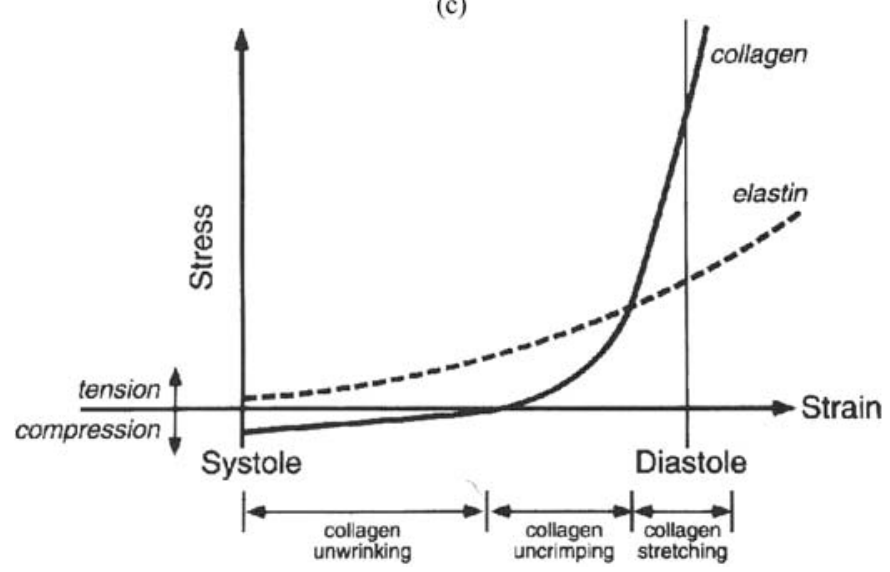

(b)

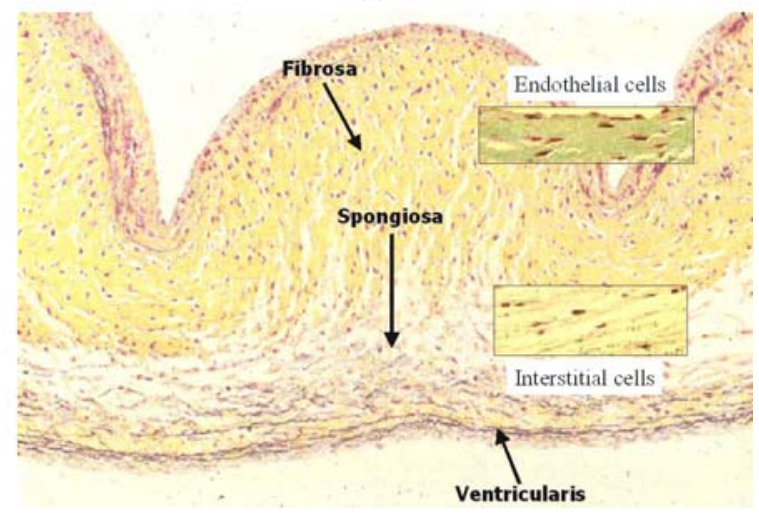

(d)

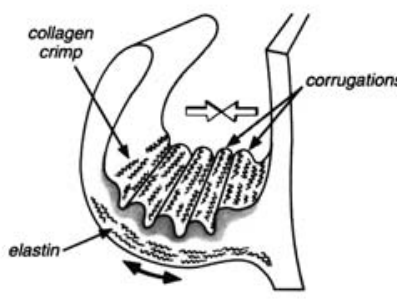

Systole

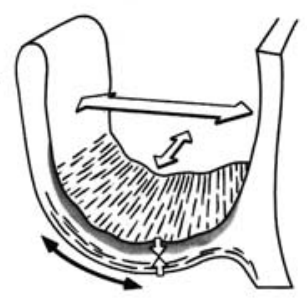

Diastole

FIGURE 1. Specialized ECM enables dynamic aortic valve function. (a) Photograph of the aortic valve in open and closed position (from the aorta). (b) Aortic valve histology emphasizing trilaminar structure and presence of valvular interstitial and endothelial cells. (c) Biomechanical cooperativity between elastin and collagen during valve motion. (d) Schematic depiction of layered aortic valve cuspal structure and configuration of collagen and elastin during systole and diastole. (a) and (b) reproduced by permission from Schoen FJ. "Valvular heart disease: General principles and stenosis," IN: Cardiovascular Pathology, 3rd Ed, Silver MD, Gotlieb Al, Schoen FJ (eds.), WB Saunders 2001, pp. 402-442; (c) and (d) reproduced by permission from Schoen FJ. Aortic valve structure-function correlations: Role of elastic fibers no longer a stretch of the imagination. J Heart Valve Dis 6: 1-6, 1997.

TABLE 2. Key structural elements of heart valves.

\begin{tabular}{|c|c|c|}
\hline Element & Sub-structure & Function \\
\hline \multirow[t]{3}{*}{ Extracellular matrix } & Collagen & $\begin{array}{l}\text { Provides strength and stiffness to maintain coaptation during diastole, when } \\
\text { cusp has maximal area }\end{array}$ \\
\hline & Elastin & Extends in diastole; contracts in systole to minimize cusp area \\
\hline & Glycosaminoglycans & Accomodates shear of cuspal layers, cushions shock during valve cycle \\
\hline \multirow[t]{2}{*}{ Cells } & Interstitial & Synthesize ECM; express MMPs and TIMPs that mediate matrix remodeling \\
\hline & Endothelial & $\begin{array}{l}\text { Maintain nonthrombogenic blood-tissue interface; regulate immune and } \\
\text { inflammatory reactions }\end{array}$ \\
\hline Blood vessels & & $\begin{array}{l}\text { Few and focal; valve cusps and leaflets sufficiently thin to be nourished by } \\
\text { diffusion from the heart's blood }\end{array}$ \\
\hline Nerves & & Present, with uncertain function \\
\hline \multirow[t]{4}{*}{ Other principles } & Corrugations & $\begin{array}{l}\text { Accordian-like folds in cusps; allows cuspal shape and dimensions to vary with } \\
\text { cardiac cycle }\end{array}$ \\
\hline & Crimp & Microscopic collagen folding, allows lengthening at minimal stress \\
\hline & Anisotropy & Permits differences in radial and circumferential extensibility \\
\hline & Cords & Macroscopic collagen alignment; transfers forces from cusps to aortic wall \\
\hline
\end{tabular}


transplanted. The aortic valve cusps undergo substantial changes in shape and dimension during the cardiac cycle (see Fig. 1a). Microscopically, the aortic valve is composed of three distinct layers: (1) the ventricularis closest to the inflow surface, rich in elastin, (2) the fibrosa closest to the outflow surface, primarily composed of densely packed collagen, and (3) the centrally located spongiosa, largely composed of glycosoaminoglycans (GAGs). Together, collagen, elastin, and GAGs comprise the valvular ECM (see Fig. 1b). Studies of normal, pathological, and substitute valves have demonstrated that the principal determinant of valve durability is the valvular ECM, whose quantity and quality depend on the viability and function of valvular interstitial cells (VIC). ${ }^{145}$ Recent research suggests that cell-matrix interactions in heart valves are highly stress-dependent and likely reciprocal. In vivo, heart valve leaflets experience a dynamic and complex mechanical stress state during every cardiac cycle: sheer stress due to blood flow (open valve), flexure (opening and closing), and tension (closed valve). ${ }^{92,93}$ Forces acting on the valve at the macroscopic level (pressure, sheer stress, and tension) are translated into specific biomechanical responses at the tissue level (collagen uncrimping, reorientation, and fiber compaction) which are transduced into a VIC response at the cellular level (with intracellular signaling events leading to changes such as increased alpha smooth muscle actin ( $\alpha$-SMA) expression, increased VIC stiffness, and increased ECM biosynthesis). Indeed, the higher absolute pressure and transvalvular pressure gradients on the left side of the heart impose larger local tissue stress on the VICs than those on the right side, which leads to higher VIC stiffness (through $\alpha$ SMA content) and collagen biosynthesis in the left-sided valves. ${ }^{94}$

Complex microstructural rearrangements and several specializations of collagen accommodate the cyclical pressure fluctuations during the cardiac cycle. ${ }^{143}$ Collagen fibers in a planar orientation in the fibrosa comprise the strongest portion of the leaflet that is responsible for bearing diastolic stress. GAGs in the spongiosa probably serve predominantly as a shock and shear absorber. The large cuspal deformation during the cycle between systole and diastole is facilitated by biomechanical cooperativity between collagen and elastin (see Fig. 1c). Collagen fibrils are inelastic and incapable of supporting large strains; they therefore have adaptations (macroscopic corrugations and microscopic crimp) that permit collagen stretching at minimal stress by unfolding (Fig. 1d). During valve opening, elastin stretches during extension of collagen crimp and corrugations. When the valve is closed, the collagen is fully unfolded and the load is shifted from elastin to collagen; elastin restores the contracted configuration of the cusp during systole.

Two types of cells are present in the aortic valve: endothelial cells covering the surface and interstitial cells with variable properties of fibroblasts, smooth muscle cells, and myofibroblasts in the interior (see Fig. 1b). ${ }^{1,121,168,169}$ Like endothelial cells elsewhere in the circulation, valvular endothelial cells (VEC) maintain a nonthrombogenic blood-tissue interface and regulate immune and inflammatory reactions. Nevertheless, endothelial cells isolated from different vascular and valvular sources display differences in gene expression and other properties (endothelial cell heterogeneity). ${ }^{21}$ Indeed, heart valve endothelial cells are different from those in the aorta. ${ }^{16,17}$ For example, in response to mechanical stress, porcine aortic valve endothelial cells align perpendicular to flow whereas endothelial cells from the aorta align parallel to flow and their gene expression is different from that of aortic endothelial cells exposed to the same mechanical environment. These differences suggest a unique phenotype of VEC not mimicked by vascular cells and could have implications for cardiovascular cell biology and cell-source considerations for tissue-engineered heart valves. Moreover, different transcriptional profiles are expressed by the endothelium on the aortic side versus ventricular side of normal adult pig aortic valves. ${ }^{155}$ The reasons for these differences are not yet known.

VIC, the most numerous valvular cell type, synthesize ECM and express matrix degrading enzymes, metalloproteinases (MMPs), and their inhibitors (TIMPs) that mediate matrix remodeling. ${ }^{1,169}$ Moreover, VIC comprise a dynamic population of resident cells of diverse and dynamic phenotypes, in a spectrum that ranges from fibroblast-like to myofibroblast-like; their phenotype is regulated by environmental conditions. ${ }^{1,25,121,168,169}$, We and others have evaluated VIC phenotypes in normal and diseased human valves. In adult heart valves in situ, VIC are quiescent and display a fibroblast-like phenotype, characterized by the presence of vimentin (intermediate filaments), and very low levels of $\alpha$-SMA, MMP-13 (proteolytic enzymes), and SMemb (non-muscle myosin heavy chain). Indeed, only $2-5 \%$ of normal adult VIC express $\alpha$-SMA, which is a marker of myofibroblast-like function. ${ }^{1,121,142,148}$ Myofibroblasts are activated fibroblasts that synthesize and remodel the specialized ECM, facilitate tissue remodeling and wound healing, and play a pathological role in fibrotic disease. ${ }^{99,148}$ In contrast, as demonstrated by previous in-vitro studies using isolated cells cultured from heart valves, $56-78 \%$ of cells are $\alpha$-SMA-positive. ${ }^{169}$ This suggests that removal of cells from the environment of the intact valve (i.e., in culture) or their manipulation stimulates VIC. Moreover, treatment of isolated VICs with TGF$\beta$ strongly activates interstitial cells to the myofibroblast phenotype. ${ }^{177}$

Biomechanical and biochemical factors play an important and potentially synergistic role in determining the local homeostatic environment of the aortic VIC. As demonstrated in in-vitro studies, mechanical stimulation (tension) and cytokine stimulation (TGF- $\beta 1$ ) were found to 
synergistically alter the contractile ( $\alpha$-SMA) and biosynthetic (heat shock protein, Hsp 47) proteins of aortic VICs to a greater extent than each factor alone. ${ }^{93}$ The need for mechanical stimulation and/or cytokines and potentially other soluble factors for the maintenance of appropriate cellular biosynthetic activity will be an important influence on tissue engineering efforts.

\section{HEART VALVE DEVELOPMENT, MATURATION, ADAPTATION, AND REPAIR}

A thorough understanding of developmental biology, physiology, and pathophysiology of heart valves will likely inform tissue engineering. Indeed, some of the processes and regulatory pathways active in valvular development and maturation may be recapitulated in tissue engineered valves. During embryological development, the three germ layers-ectoderm, endoderm, and mesoderm-give rise to cells that differentiate to form the body's tissues and complex organs. The heart develops primarily from the embryonic layer called mesoderm. ${ }^{160}$ The initial commitment of mesodermal precursor cells to a cardiac lineage depends on complex signaling pathways. ${ }^{106}$ Cardiac myocytes become organized into a linear heart tube that subsequently undergoes looping. ${ }^{174}$ Growth of the looped heart tube and development of septa leads to the multichambered heart.

During cardiac development, the valve cusps and leaflets originate as outgrowths (known as endocardial cushions) from mesodermal derived connective tissue called mesenchyme. ${ }^{30}$ Endothelial cells lining the inside surface of the cushion forming area undergo an epithelial-tomesenchymal transdifferentiation (EMT) and migrate from the blood-contacting internal heart surface deep into the connective tissue of the subendocardium (called cardiac jelly) to become precursors of mature VICs. ${ }^{5}$ Widespread in embryological development, epithelial mesenchymal transitions comprise a series of cell-cell and cell-matrix interactions that release epithelial cells from a surface and confer the ability to move through three dimensional ECM and synthesize ECM. ${ }^{124}$ The newly formed mesenchymal cells remodel the cushions into leaflets and cusps. Evidence for EMT is provided by mesenchymal cellular expression of $\alpha$-SMA, a marker that is not typically expressed by endothelial cells. ${ }^{31,110}$ Numerous signaling pathways, growth and transcriptional factors (including vascular endothelial growth factor [VEGF], nuclear factor in activated $\mathrm{T}$ cells [NFATc1], and Notch) regulate the process of heart valve formation. ${ }^{5,9,43,78}$

We studied the subsequent maturation and evolution of human semilunar valves in fetuses, neonates, children, and adults. ${ }^{1}$ We demonstrated that fetal valves contain immature activated cells and are dynamic and adaptable structures; the architecture, collagen content, and organization were immature compared with that of adult valves. Dur- ing valve development and maturation, fetal VIC have a myofibroblast-like phenotype, characterized by expression of $\alpha$-SMA, MMP-13, and SMemb, and continuously remodel the ECM. The cells become quiescent in the normal valve post-natally, suggesting progressive adaptation to the prevailing hemodynamic environment. Moreover, the cell density progressively decreases (by nearly $90 \%$ ) throughout life.

The role of myofibroblasts in valvular wound healing, adaptation, and remodeling is best illustrated by comparisons of normal, diseased, autograft, and tissue engineered valves. ${ }^{121}$ In conditions of disease (e.g., myxomatous mitral valve), ${ }^{117}$ adaptation (early pulmonary-to-aortic autograft), ${ }^{120}$ or remodeling (tissue engineered valves in-vitro and in-vivo), ${ }^{118}$ VICs have an activated myofibroblast phenotype, similar to that of fetal valves. Normal and pathological cardiac valves respond to environmental conditions, such as mechanical loading, by cell activation and matrix remodeling. In contrast, following return of a stable equilibrium of mechanical state in development, adaptation, or remodeling, VIC return to their normal quiescent fibroblast phenotype, as exemplified by late pulmonary-to-aortic autografts ( $>3$ years postoperative) and tissue engineered valves implanted in-vivo. Therefore, heart valves respond to environmental change via reversible phenotypic modulation of their resident VICs.

\section{SCAFFOLDS FOR TISSUE ENGINEERING: GENERAL CONCEPTS}

A widely accepted paradigm of tissue engineering comprises (1) a scaffold, that is pre-seeded with (2) cells, followed by (3) an in-vitro stage of tissue formation typically conducted in a bioreactor (that recapitulates a physiological metabolic and mechanical environment), and subsequently, following implantation of the construct, (4) an invivo stage of tissue growth and remodeling (Fig. 2, Pathway A). ${ }^{77}$ The key pathophysiological processes occurring during the in-vitro and in-vivo phases are cell proliferation and migration, ECM production and organization, scaffold degradation, and tissue remodeling. The in-vivo but not the in-vitro phase can involve recruitment of the recipient's inflammatory cells. The resulting tissue engineered construct will likely contain some combination of seeded and/or recipient-derived new cells. An alternative pathway (Fig. 2, Pathway B) utilizes an unseeded scaffold that incorporates biological "information" designed to attract and direct the formation of circulating endogenous precursor cells (potentially both endothelial and mesenchymal) invivo. Both of these pathways are considered in detail in subsequent sections of this paper. Moreover, host inflammatory cells may play a role in the in-vivo phase of either approach. In the following sections we examine the characteristics of biodegradable synthetic scaffolds and natural allograft or xenograft scaffolds; a composite biodegradable polymer 
Pathway A

Pathway B

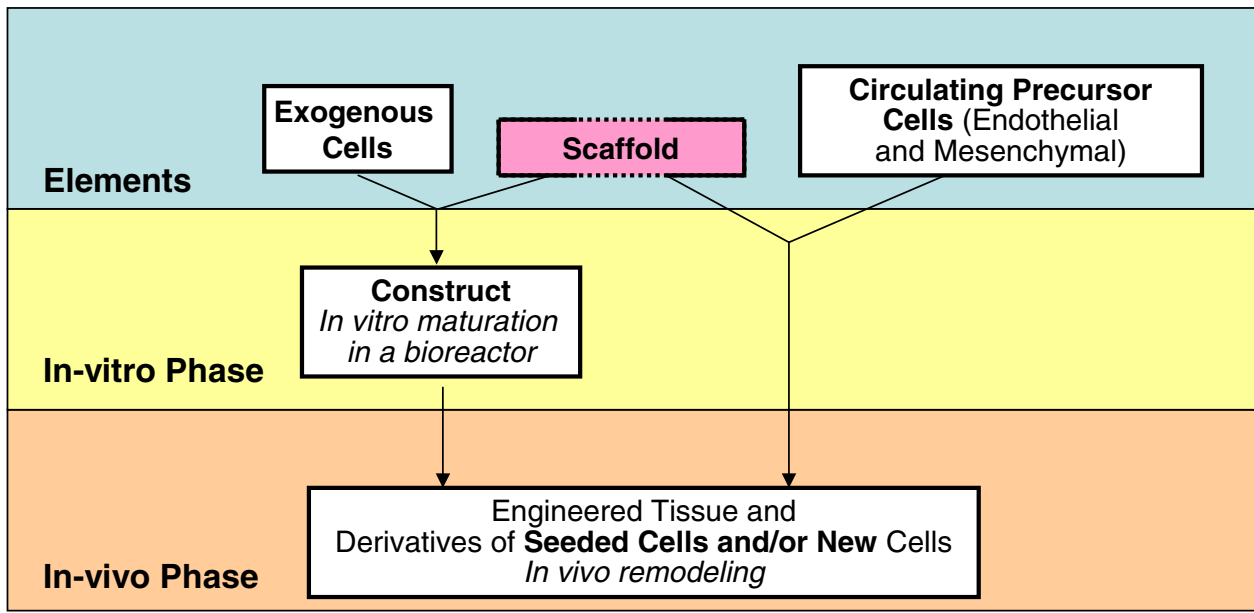

Pathway A: Conventional Paradigm

-Combine appropriate cells and scaffold

- Grow valve in-vitro in a bioreactor that

provides mechanical and metabolic support

-Implant in anatomic site in-vivo
Pathway B: Modified Paradigm

-Implant appropriate scaffold in-vivo

-Enhance release, targeted recruitment, adhesion, migration, proliferation,

differentiation, and function of desired cell

populations

-Avoid unwanted recruitment

FIGURE 2. Tissue engineering paradigms. (Pathway $A$ ) The conventional paradigm of tissue engineering comprises a scaffold that is seeded with cells, an in-vitro stage of tissue formation typically conducted in a bioreactor, and an in-vivo stage of tissue growth and remodeling. The key pathophysiological processes occurring during the in-vitro and in-vivo phases are cell proliferation, ECM production and organization, scaffold degradation, and tissue remodeling. The resulting tissue engineered construct will contain some combination of seeded and/or new cells. A modified paradigm (Pathway B) might utilize an unseeded scaffold that is fabricated with biological "information" designed to attract and provide a suitable substrate for differentiation of circulating precursor cells in-vivo.

with collagen or other natural material may also be considered (Table 3).

\section{Synthetic Scaffolds}

Synthetic polymeric scaffolds generally have well controlled and easily reproduced properties. Ideally, a tissue engineered scaffold should be biocompatible, resorbable, have a highly porous macrostructure (necessary for cell growth, nutrient supply and waste removal) and a surface conducive to cellular attachment and potentially migration, proliferation, differentiation, matrix formation and/or remodeling. A bioresorbable scaffold serves as a temporary matrix until the seeded cells are capable of producing their

TABLE 3. Comparative analysis of scaffolds.

\begin{tabular}{|c|c|c|}
\hline & Synthetic scaffolds & Natural scaffolds \\
\hline \multirow[t]{3}{*}{ Advantages } & $\begin{array}{l}\text { Control of material structure and properties (e.g. } \\
\text { pore size, stability, degradation rate) }\end{array}$ & $\begin{array}{l}\text { Maintain architecture of the native tissue } \\
\text { (potentially valve) }\end{array}$ \\
\hline & Easily reproduced & $\begin{array}{l}\text { Maintain biological information (e.g., } \\
\text { reactive sites, growth factors) }\end{array}$ \\
\hline & Resorbable & Potentially resorbable \\
\hline \multirow[t]{4}{*}{ Disadvantages } & $\begin{array}{l}\text { Difficulty in controlling cell adhesion and tissue } \\
\text { reorganization }\end{array}$ & $\begin{array}{l}\text { Decellularization may alter physical } \\
\text { properties }\end{array}$ \\
\hline & $\begin{array}{l}\text { Inflammation due to incomplete polymer } \\
\text { degradation or lack of biocompatibility }\end{array}$ & Difficulty of cell penetration into interior \\
\hline & $\begin{array}{l}\text { Space formerly occupied by polymer and its } \\
\text { interstices is replaced by fibrosis/scar }\end{array}$ & May induce immunologic reaction \\
\hline & Limited perfusion to deep cells & Potential for calcification \\
\hline
\end{tabular}


own matrix proteins; the chemical and physical properties and the rate of degradation are generally tailored to the application and the rate of new tissue evolution. ${ }^{41,53,69,83,100}$

Polyglycolic acid (PGA) and polylactic acid (PLA) and their copolymers are currently the synthetic, biodegradable polymers most widely considered for tissue engineering applications. PGA is a highly crystalline, linear, aliphatic polyester, with a high melting point and low solubility in organic solvents. PGA was used as the first totally synthetic resorbable suture, commercially available under the trade name "Dexon" since 1970 . PGA is rapidly resorbable; thus, Dexon sutures tend to lose their mechanical strength rapidly, usually within 2 to 4 weeks after implantation. Copolymers of the hydrophilic PGA with the more hydrophobic PLA increase the range of material properties and hence possible applications; for example, the addition of PLA limits the water uptake and reduces the rate of hydrolysis (the predominant model of degradation) as compared to PGA alone. Considered safe, nontoxic, and biocompatible, these polymers are used successfully in a number of approved medical implants. ${ }^{48}$

The use of a synthetic scaffold introduces challenges in the regulation of cell adhesion and three-dimensional tissue reorganization since such materials are usually isotropic and ECM proteins are not usual constituents of synthetic polymers. For example, PGA, PLA, and their copolymers are generally considered poor substrates for cell growth in-vitro. ${ }^{71}$ Therefore, bioactive synthetic biomaterials are being developed for use as three-dimensional microenvironments that mimic ECM function. ${ }^{84,85}$ Recent advances include nanofibrillar networks formed by self-assembly of small molecules and artificial ECM networks from protein polymers or synthetic polymers that present bioactive ligands and respond to cell-secreted signals to enable remodeling. ${ }^{115}$

An especially attractive concept is that of smart biomaterial scaffolds, which carry spatial and chemical information that affects cellular function and/or responds to changes in the environment. ${ }^{76}$ Smart scaffolds are exemplified by biodegradable elastic shape-memory polymers that predictably alter their shape with changes in temperature ${ }^{79}$ and polymers that transition between hydrophobic and hydrophilic states in response to electric potential. ${ }^{2,75}$ Moreover, normal tissue culture dishes grafted with a temperature sensitive polymer PIPAAm (poly $N$-isopropylacrylamide) respond to temperature changes, which alter the adhesion properties of cells to this matrix. At elevated temperatures (above $37^{\circ} \mathrm{C}$ ), the dish surfaces are relatively hydrophobic and cells attach, whereas at lower temperatures $\left(20^{\circ} \mathrm{C}\right)$ the polymer surface becomes hydrophilic and swells, forming a hydration layer between the dish surface and the cultured cells. The cells along with their framework ECM spontaneously detach and may be harvested as intact sheets. ${ }^{186}$ As the technology develops, smart scaffolds may prove important to applications of stem cells in tissue engineering; for example, a new three dimensional material with the ability to direct the differentiation of neural progenitor cells into a specific lineage without the help of growth factors has been reported. ${ }^{154}$

Tissue engineered biomaterial constructs must also exhibit mechanical and structural properties comparable to the native tissue they replace, including dynamic anisotropic behaviors optimized for tissue specific function, from the time of implantation of a construct through the lifetime of the recipient. This implies central requirements of relatively constant mechanical properties despite potentially considerable tissue remodeling and scaffold resorption. Moreover, mechanical anisotropy (certainly a characteristic of the natural valves $)^{92}$ may be desirable; towards this end, electrospun scaffolds were fabricated which exhibited highly anisotropic mechanical properties that resembled native pulmonary heart valve cusps. ${ }^{136}$

Potential undesirable features of synthetic scaffolds include local tissue inflammation owing to the foreign body reaction and slow and/or incomplete polymer degradation. As the scaffold degrades, the space formerly occupied by a polymer and its interstices is progressively filled by cells and ECM which may eventuate in fibrosis (scar) that poorly resembles specialized native tissue and may contract and distort during maturation. In some cases, cells on the scaffold periphery are healthy and resemble native differentiated parenchymal (i.e., function-specific) tissue whereas cells at the interior become necrotic due to restricted deep delivery of oxygen and nutrients, and removal of wastes.

\section{Natural Scaffolds}

Alternative to synthetic scaffolds, natural scaffolds usually comprise pure ECM components (such as collagen or fibrin) or decellularized but otherwise intact allograft or xenograft tissue (such as heart valve or small intestinal submucosa). In cardiovascular tissue engineering, multi-step static seeding methods have been most commonly used; alternatively, efficient single step seeding may be achieved via cellular encapsulation in collagen and fibrin gels. Collagen based constructs seeded with vascular smooth muscle and/or endothelial cells have been utilized to generate tubular blood vessels, ${ }^{178}$ one-dimensional strings to serve as a component of composite aortic valve cusps ${ }^{150}$ or chordae tendineae ${ }^{151}$ and molds for heart valve leaflets. ${ }^{171}$ Cells entrapped in collagen gels contract and compact the gels in a process similar to the contraction of a wound during healing, thus increasing their density and enhancing their properties. ${ }^{170}$ Alternatively, cells can be encapsulated in an autologous fibrin gel which initially serves to obtain uniform cell distribution and to improve the seeding efficiency. ${ }^{66,97,134,187}$ With gel encapsulated cells, newly synthesized ECM accumulates in the immediate extracellular space, rather than diffusing into the surrounding 
medium. ${ }^{187}$ Reported limitations of the encapsulated cell approach to tissue engineering include excessive shrinkage of the gel/cell construct ${ }^{66}$ and the possibility that the entrapped cells become necrotic or apoptotic. ${ }^{166}$ In one invitro study, cells encapsulated in a fibrin gel were seeded onto a synthetic PGA scaffold to optimize tissue formation and organization. Following fibrin degradation, the underlying synthetic scaffold contributed to the structural integrity of the developing tissue. ${ }^{97}$ Additionally, hyaluronan, a viscoelastic and broadly biocompatible material that plays a role during embryonic cardiac development, is also being explored as a potential ECM scaffold material. ${ }^{88,129}$

Some investigators favor enzymatically decellularized tissue as a natural scaffold. This treatment is done to decrease antigenicity and the risk of calcification (both of which are enhanced by cells and their debris). The hope with a decellularized scaffold is that preseeded or endogenous circulating cells can repopulate such a scaffold. A decellularized allograft or xenograft tissue scaffold may best serve as a template for cellular attachment and retain many of the mechanical and structural properties of native tissue such as tensile strength and unique ECM composition. ${ }^{54}$

Decellularized porcine small intestinal submucosa (SIS) has been studied extensively as a natural resorbable scaffold material that does not require cell seeding. ${ }^{7}$ In both animal and human clinical studies, SIS was rapidly remodeled by the host tissue. ${ }^{133}$ Useful in implants ranging from particulate material related to the bladder, ${ }^{182}$ to sheets that might be used to repair the infarcted left ventricle, ${ }^{132}$ SIS has exhibited good vascularization and tissue growth without excessive inflammation and foreign body reaction. The success of SIS has been attributed to its intrinsic ECM proteins, GAGs, cytokines, and growth factors (VEGF and TGF- $\beta$ ). ${ }^{130}$

\section{CELLS FOR TISSUE ENGINEERING: GENERAL CONCEPTS}

While the ultimate goal of tissue engineered heart valves is to recapitulate the matrix and cells found in native tissue, there exists variability in potential strategies and sources of cells. The predominant paradigm provides cell-seeded scaffolds (biodegradable or natural) with the ingredients and environment to form tissue and mature in-vitro in a bioreactor, in order to generate a construct which is then implanted in-vivo in the desired anatomic location (recall Fig. 2, Pathway A). Potential cellular sources for seeding of scaffolds to fabricate heart valves include differentiated tissue-specific cells (such as endothelial and/or smooth muscle cells ${ }^{91}$ ) and stem cells that may be autologous or allogenic. In a clinical study, an in-vitro endothelialization procedure, in which femoropopliteal arterial grafts composed of expanded polytetrafluoroethylene (ePTFE) were confluently lined with cultured autologous endothelial cells before implantation, was assessed for its ability to improve the long-term patency of these prosthetic bypass grafts. The results (regrettably not compared with concurrent unseeded control grafts) suggested that autologous endothelial cell lining improved the patency of these small-diameter vascular grafts. ${ }^{26}$ Another option is to harness the potential of endogenous cells by utilizing decellularized biological scaffolds that contain intact ECM and other chemical signals necessary to recruit the appropriate cell populations (recall Fig. 2, Pathway B and see below); unseeded scaffolds that could attract endogenous cells in-vivo to the site of implantation might permit bypassing the in-vitro stage of cell seeding, by facilitating repair by endogenous cells. Nevertheless, presently used tissue heart valve replacements do not endothelialize from circulating blood to a degree sufficient to provide functional benefit. This holds true for both glutaraldehyde-pretreated porcine valves,${ }^{59}$ in which the barrier to endothelialization may result from toxicity induced by residual glutaraldehyde, ${ }^{37}$ and cryopreserved allograft heart valves. ${ }^{95}$

The unique properties of stem cells, such as multipotency and capacity for self-renewal, make them attractive cells for tissue engineering. ${ }^{22,46}$ Stem cells are found in the bone marrow of adults, including hematopoietic stem cells (which form the mature blood cells), endothelial stem cells (endothelial progenitor cells, which form components of the cardiovascular system), and mesenchymal stem cells (which form bone, cartilage, muscle, fat, and fibroblasts). Bone marrow-derived adult somatic stem cells are an attractive cell source because they are multipotential cells, in principle capable of differentiation, transformation, and regeneration. We will not discuss stem cells of embryonic origin owing to the complicated scientific ethical and moral issues surrounding their usage. Bone marrow comprises an ideal cell source for tissue engineering because its cells are easily accessible, its primary isolate is a cell suspension that is easier to process and less prone to contamination than solid tissue, and bone marrow will likely be the primary source of cells for endogenous repopulation. ${ }^{164}$ Throughout post-natal life, both bone marrow-derived and organresident adult stem cells continuously regenerate some tissues (such as skin epithelium, intestinal epithelium, blood cells, and liver when stimulated). Nevertheless, increasing evidence suggests that the heart and the brain can regenerate some of their mass, defying the conventional wisdom that these organs cannot replenish cells lost as a result of maturation, senescence, and injury. ${ }^{33,81}$

Endothelial progenitor cells (EPCs) are bone marrowderived hematopoietic stem cells capable of differentiating into the endothelial cells that line the blood vessels and cardiac valves. ${ }^{56,61,125,173}$ EPCs maintain vascular homeostasis by promoting reendothelialization after endothelial injury and neovascularization after tissue ischemia. Endothelial progenitor-derived cells obtained from peripheral blood have been expanded in-vitro and seeded on a three 
dimensional biodegradable PGA-PLLA scaffold. When seeded alone, they maintained an endothelial phenotype for the entire six-week duration of implantation and when co-seeded with smooth muscle cells, the endothelial progenitor derived endothelial cells formed microvessels on the scaffold. ${ }^{184}$ EPCs obtained from peripheral blood have also been used to line small diameter vascular grafts. ${ }^{70}$

Mesenchymal stem cells (MSCs), have the potential for differentiating into osteogenic, chondrogenic, adipogenic, and myogenic lineages. ${ }^{13,116}$ These can be isolated from adult bone marrow and represent another adult stem cell population that can be used as a cellular source in tissue engineering. ${ }^{86,90,112}$ The concept of continuous replacement of connective tissue with bone marrow mesenchymal stem cells parallels the known continuous replacement of blood by bone marrow hematopoietic cells. Cultured MSCs display the spindle shape morphology characteristic of myofibroblasts and express cell markers characteristic of VIC. Upon implantation, these cells retain profiles identical to those seen in-vitro. Following myocardial infarction in a mouse model, injected MSCs improve recovery of the infarcted tissue and were thought to differentiate into cardiac myocytes, endothelial cells, and vascular smooth muscle cells. ${ }^{107}$ Marrow progenitor cells or multipotent adult progenitor cells (MAPCs) have many attributes of MSCs but they are reported to expand indefinitely (compared to 1 million fold expansion of MSCs) and may have lineage potential that includes ectodermal and endothelial cell types, making them similar to embryonic stem cells. ${ }^{65}$

\section{BIOREACTORS FOR TISSUE ENGINEERING}

Mechanical stimulation through the use of bioreactors during in-vitro tissue development is widely utilized in cardiovascular tissue engineering for improving tissue formation, organization, and function. The bioreactor exposes the developing tissue to mechanical conditioning, primarily through cyclical flow and pressure changes that mimic physiological conditions. Bioreactors have been developed that use flow ${ }^{52,101,158,181}$ and $\operatorname{strain}^{103,161}$ as their main mechanical cues to engineer blood vessels and heart valves. For the engineering of heart valves, a diastolic pulse duplicator bioreactor has been developed to mimic only the diastolic phase of the cardiac cycle, resulting in dynamic tissue straining. ${ }^{96}$ Additionally, electrical stimulation (designed to mimic native excitation-contraction coupling) has been used as a cue to enhance the structure and function of pulsatile myocardium in-vitro. ${ }^{123}$ The optimal conditioning protocol depends on numerous parameters such as the sensitivity of the cell phenotype to mechanical cues, the scaffold used, the transfer of the mechanical cues from the scaffold to the cells, and the magnitude and type of mechanical cues.

\section{KEY IN-VIVO STUDIES IN HEART VALVE TISSUE ENGINEERING}

Many published studies have used in-vitro methods to investigate critical variables and demonstrated "proof-ofprinciple" of important concepts in tissue engineering germane to heart valves. Only a few key studies have been conducted using synthetic and natural scaffolds in animal models (Table 4). Early studies focused on the design of individual valve leaflets ${ }^{188}$ whereas later studies emphasize design of complete valved conduits. In this section, we focus on studies in which scaffolds seeded in-vitro were implanted in-vivo. Following this section, we discuss the possibility that the recipient can provide all the cells needed to populate and/or remodel a scaffold to yield a functional heart valve in-vivo.

\section{Implant Studies Using Synthetic Scaffolds Seeded In-Vitro}

In this approach a bioabsorbable polymer provides a temporary scaffold until cells seeded in-vitro produce their own matrix proteins (see Fig. 2, Pathway A). The biodegradable polymer PGA and related compounds have been used as biodegradable synthetic polymer scaffolds because this polymer (albeit with suboptimal mechanical properties) is well characterized and approved by the FDA in sutures and other devices for human implantation. In one of the earliest experiments in the field, an isolated tissue engineered heart valve leaflet was implanted in the pulmonary position of sheep using a PGA scaffold seeded with vascular wall cells. ${ }^{152,153}$ Histologic evaluation of the constructs showed development of an ECM, endothelialization of the surface, and scaffold remodeling. While this preliminary experiment showed that a tissue engineered valve leaflet constructed from its cellular components can function in the pulmonary valve position, the resultant engineered tissue heart valve cusps were thicker, stiffer, and less pliable than native valves.

To alleviate the problem of scaffold thickness and rigidity, Hoerstrup et al. ${ }^{52}$ designed a scaffold composite that combined PGA with the strong, flexible poly-4hydroxybutyrate (P4HB) formed in the configuration of a trileaflet heart valve. $\mathrm{P} 4 \mathrm{HB}$ is added to prolong mechanical integrity because PGA degrades faster than P4HB (approximately 4 weeks versus 8 weeks respectively). This scaffold was seeded with differentiated autologous vessel-derived ovine endothelial cells and smooth muscle cells. To simulate a biomimetic environment during tissue formation, the constructs were grown for varying time points in an in-vitro pulse duplicator system under gradually increasing flow and pressure conditions while controls were grown in static nutrient medium. After 14 days of in-vitro culture, the constructs (valves) grown in the bioreactor showed significantly increased DNA content, higher formation of matrix proteins, a more organized histological structure, and more 
TABLE 4. Representative, animal, and clinical implant studies using seeded and non-seeded matrices.

\begin{tabular}{|c|c|c|c|}
\hline Study & Scaffold & Cells & Site \\
\hline \multicolumn{4}{|l|}{ In-vitro seeding } \\
\hline (A) Shinoka (1995-96) & Polyglycolic acid (PGA) & $\begin{array}{l}\text { Autologous ovine endothelial } \\
\text { cells and fibroblasts }\end{array}$ & $\begin{array}{l}\text { Replacement of one pulmonary } \\
\text { valve (PV) leaflet in sheep }\end{array}$ \\
\hline (B) Hoerstrup (2000) & $\begin{array}{l}\text { Poly-4-hydroxybutyrate (P4HB) } \\
\text { coated PGA }\end{array}$ & $\begin{array}{l}\text { Autologous ovine endothelial } \\
\text { cells and myofibroblasts }\end{array}$ & $\begin{array}{l}\text { Replacement of all three PV } \\
\text { leaflets in sheep }\end{array}$ \\
\hline (C) Steinhoff (2000) & $\begin{array}{l}\text { Decellularized pulmonary sheep } \\
\text { valves }\end{array}$ & $\begin{array}{l}\text { Autologous ovine endothelial } \\
\text { cells and myofibroblasts }\end{array}$ & PV conduits implanted into sheep \\
\hline (D) Dohmen (2002) & $\begin{array}{l}\text { Decellularized cryopreserved } \\
\text { pulmonary allograft }\end{array}$ & $\begin{array}{l}\text { Autologous human vascular } \\
\text { endothelial cells }\end{array}$ & $\begin{array}{l}\text { Reconstruction of the right } \\
\text { ventricular outflow tract (RVOT) } \\
\text { in a human patient }\end{array}$ \\
\hline (E) Perry (2003) & P4HB coated PGA & $\begin{array}{l}\text { Autologous ovine mesenchymal } \\
\text { stem cells }\end{array}$ & $\begin{array}{l}\text { In-vitro only, no in vivo } \\
\text { implantation }\end{array}$ \\
\hline (F) Iwai (2004) & $\begin{array}{l}\text { Poly(lactic-co-glycolic acid) } \\
\text { (PLGA) compounded with } \\
\text { collagen microsponge }\end{array}$ & $\begin{array}{l}\text { Autologous endothelial and } \\
\text { smooth muscle cells; w/ and } \\
\text { w/o in-vitro precellularization }\end{array}$ & $\begin{array}{l}\text { Patch implant in canine } \\
\text { pulmonary artery }\end{array}$ \\
\hline (G) Sutherland (2005) & $\begin{array}{l}\text { PGA and poly-L-lactic acid } \\
\text { (PLLA) }\end{array}$ & $\begin{array}{l}\text { Autologous ovine mesenchymal } \\
\text { stem cells }\end{array}$ & $\begin{array}{l}\text { Replacement of all three PV } \\
\text { leaflets in sheep }\end{array}$ \\
\hline \multicolumn{4}{|c|}{ In-vivo only (No in-vitro seeding) } \\
\hline (A) Matheny (2000) & $\begin{array}{l}\text { Porcine small intestinal } \\
\text { submucosa }\end{array}$ & $\mathrm{N} / \mathrm{A}$ & $\begin{array}{l}\text { Replacement of one PV leaflet in } \\
\text { a pig }\end{array}$ \\
\hline (B) Elkins (2001) & $\begin{array}{l}\text { Decellularized (using SynerGraft } \\
\text { treatment) human (CryoValve } \\
\text { SG) and sheep pulmonary } \\
\text { valves }\end{array}$ & $\mathrm{N} / \mathrm{A}$ & $\begin{array}{l}\text { SynerGraft-treated and } \\
\text { cryopreserved sheep PVs } \\
\text { implanted in RVOT in sheep; } \\
\text { CryoValve SG human PVs } \\
\text { implanted in patients }\end{array}$ \\
\hline (C) Simon (2003) & $\begin{array}{l}\text { Decellularized porcine Synergraft } \\
\text { valve }\end{array}$ & $\mathrm{N} / \mathrm{A}$ & Implanted in RVOT in children \\
\hline
\end{tabular}

favorable mechanical properties than did constructs grown under static culture conditions. Based on these preliminary in-vitro studies, seeded constructs that had been matured invitro in the bioreactor for 14 days were implanted in-vivo as a pulmonary valve replacement in an ovine animal model. After 20 weeks in vivo, the polymer had been degraded and replaced by a partially endothelialized uniform, layered tissue with layer-specific ECM predominance similar to that of the native valve, including a layer containing elastin near the inflow surface, gylcosaminoglycans centrally, and a fibrous layer with abundant collagen near the outflow surface. Mechanical properties were comparable to those of native tissue at 20 weeks. ${ }^{52}$ Particularly exciting was the presence of a trilaminar structure resembling the native pulmonary valve, which indicates that dynamic growth, remodeling, and asymmetric structural differentiation had occurred invivo, probably regulated by the mechanical environment.

Building on these principles, an autologous trileaflet heart valve was created from a biodegradable synthetic scaffold [PGA and poly-L-lactic acid (PLLA)] seeded with autologous bone marrow-derived MSCs. The cell-scaffold construct was cultured in-vitro then implanted into the pulmonary artery position of sheep for up to 8 months. The results showed that the construct remodeled in-vivo to a tissue with features that simulated those of native valves. In particular, the tissue-engineered valves displayed a trilami- nar distribution of cells and ECM, analogous to those of native valves-myofibroblasts immediately below the endothelium, fibroblasts expressing vimentin distributed throughout the remainder, and endothelialization. These findings support the potential use of bone marrow derived MSCs as a cell source for the fabrication of heart valves. The editorial accompanying this paper emphasized that, although proofof-concept has been demonstrated based on remodeling of the construct to a trilaminar structure following implantation, there remain numerous challenges to overcome before such technology can be used in human patients. ${ }^{6}$

\section{Implant Studies Using Biologic Scaffolds Seeded In-Vitro}

An especially attractive concept is that of a native valve biological scaffold, either decellularized xenograft ${ }^{28,72,141,163}$ or allograft, that has been seeded with autologous cells in-vitro. ${ }^{10,158}$ One study suggested that allogenic decellularized sheep matrix conduits seeded with autologous myofibroblast and endothelial cells may yield viable valves. Following almost complete removal of cells, control unseeded allogenic acellular valves implanted in sheep for up to 3 months showed partial degeneration and no interstitial tissue reconstitution whereas the counterparts seeded with autologous vascular wall cells were reported to 
show restitution of the endothelial cell surface, myofibroblasts, and matrix synthesis. ${ }^{162}$

Owing to the antigenicity of xenograft ECM proteins, xenograft scaffolds likely provide a more inflammatory stimulus than allograft scaffolds, exemplified by the cryopreserved homografts presently used clinically. ${ }^{131}$ An inflammatory reaction could weaken or scar the heart valve scaffold, making it more susceptible to biomechanical damage. Therefore, human allograft heart valves, either decellularized or not, have been considered as an alternative scaffold. Presently used cryopreserved allograft valves are effectively decellularized following several months of invivo function, yet they do not grow, remodel, exhibit active metabolic functions, or recellularize, even following longterm function. ${ }^{95}$ Moreover, decellularization may alter the physical properties of native valves and newly seeded cells may initially have difficulty growing into a decellularized matrix.

\section{HARNESSING THE REPARATIVE POTENTIAL OF CIRCULATING ENDOGENOUS CELLS: UNSEEDED SCAFFOLDS}

As discussed in the previous section, the basic paradigm of tissue engineering uses a cell seeded scaffold, an in-vitro stage of tissue formation, and an in-vivo stage of tissue growth and remodeling (see Fig. 2, Pathway A). In this section, we examine an alternative pathway (see Fig. 2, Pathway B) in which an unseeded scaffold could have the potential for attracting circulating precursor cells (endothelial and mesenchymal) in-vivo (Fig. 3).

Accumulating evidence suggests that circulating endogenous cells can be recruited in-vivo to adhere to intravascular sites via a pathway that likely mimics the adherence of inflammatory cells to the endothelium during physiological inflammation. ${ }^{73}$ EPCs promote endothelial regeneration in dog models by covering implanted Dacron grafts ${ }^{149}$ and in human studies by covering the blood-contacting surfaces of implanted ventricular assist devices, ${ }^{40,126}$ and homing to stents that have been coated with CD34 antibody (a marker found on EPCs). ${ }^{3}$ Recent studies have suggested therapeutic potential of EPCs in humans. ${ }^{125}$ Ischemic heart disease patients with naturally higher levels of EPCs had a reduced risk of death from cardiovascular causes. ${ }^{180}$ Following experimental myocardial infarction, bone marrow derived cells are recruited by selective homing to the area of injury. ${ }^{98}$ It has been suggested that intracoronary infusion of EPCs in patients with acute myocardial infarction might potentially contribute to restoring myocardial and endothelial function to the damaged area. ${ }^{109}$ Endogenous stimuli such as tissue ischemia and exogenous cytokines promote mobilization of EPCs. ${ }^{18}$ Patients with vascular trauma such as acute myocardial infarction display increased numbers of EPCs, which is positively correlated to elevated plasma VEGF. ${ }^{165}$ VEGF and other an- giogenic growth factors such as angiopoietin-1, fibroblast growth factor and stromal cell-derived growth factor-1 promote EPC mobilization and recruitment. ${ }^{172}$ One potential strategy may be to coat a scaffold with appropriate cellsignaling molecules in an effort to encourage EPC adhesion and differentiation. An experiment utilizing decellularized porcine aortic valves containing fibronectin and hepatocyte growth factor suggested that the growth factor enhances early endothelial cell recruitment and coverage of the grafts. ${ }^{108}$

Recent experimental evidence suggests that human bone marrow may be a source of progenitor cells contributing smooth muscle-like cells to adult human heart valves. ${ }^{23,157}$ Like endothelial cells, smooth muscle cells can also be recruited to sites of vascular injury. ${ }^{82,138}$ Experimental evidence in mouse models suggests that bone marrow derived smooth muscle cells may be implicated in degenerative aortic stenosis ${ }^{167}$ and atherosclerosis. ${ }^{135,137,138,139}$ Evidence of smooth muscle cell recruitment is exemplified by a prototype tissue-engineered vascular graft. In an experiment in which rat arteries were acellularized, recellularized with endothelial cells, and implanted as grafts in the femoral artery for four weeks, immunohistochemical staining of explanted grafts demonstrated a complete layer of endothelial cells on the luminal surface and smooth muscle cell repopulation. Since smooth muscle cells were not originally seeded onto the graft, the authors suggested that they were recruited to the graft from the bone marrow by a mechanism that involved endothelial cells. ${ }^{13}$

Unseeded scaffolds have been examined experimentally, with the goal of achieving in-vivo recellularization by circulating endogenous cells. In one experiment, each of four pigs had one pulmonary valve leaflet excised and replaced with a leaflet constructed from porcine SIS. Histology indicated that the implanted matrix was progressively resorbed and replaced by fibrous connective tissue that had features of adult valve. ${ }^{89}$ Alternatively, a biodegradable graft containing collagen microsponge was fabricated and tested with and without preseeding. ${ }^{60}$ In both cases (SIS and collagen microsponge) there was no thrombus formation, the scaffold was absorbed, and there was endothelialization, parallel smooth muscle cell alignment, elastin, and collagen fibers. These results suggested that the patch promoted insitu cellularization and regeneration of autologous tissue. However, an important limitation of these studies was that the implanted leaflets and patches were small; cellularization of a large implant may be less efficient.

\section{CLINICAL STUDIES USING ENGINEERED MATRICES AS HEART VALVES}

In this section we examine the limited number of studies using engineered matrices in clinical settings. One study used a decellularized pulmonary allograft seeded with autologous endothelial cells and conditioned in bioreactor to 


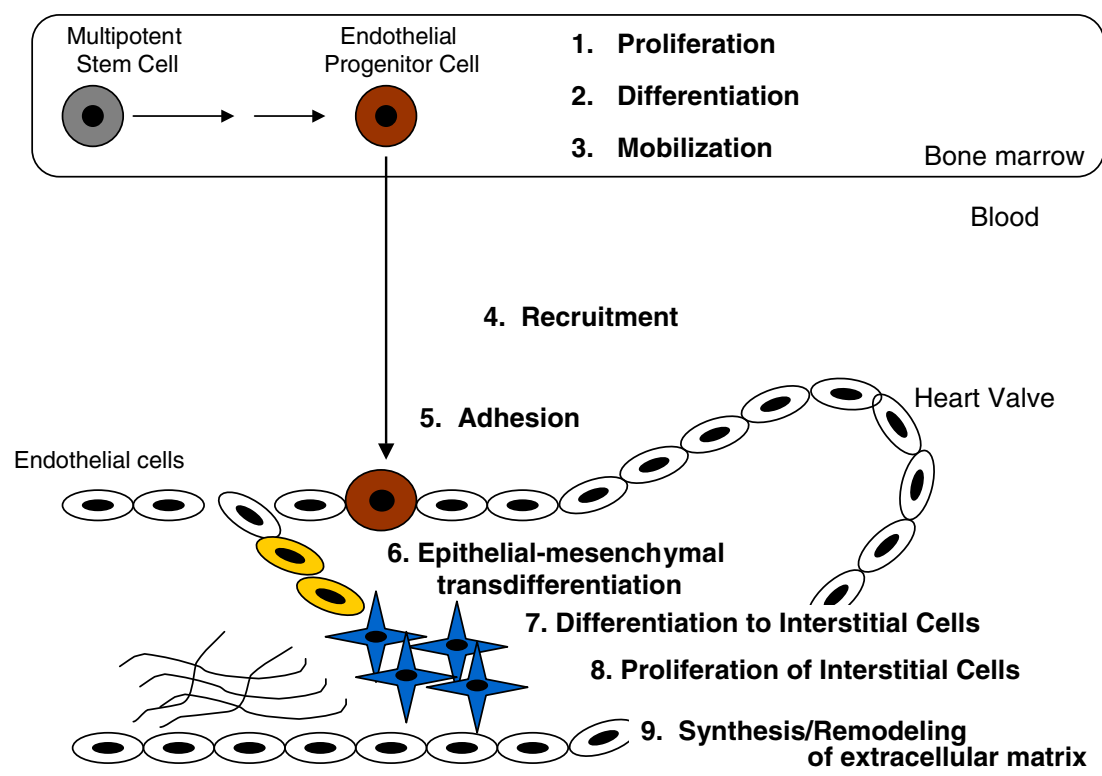

FIGURE 3. A representative hypothesis for the population of a tissue engineered heart valve by endogenous cells. Key processes include proliferation, differentiation, and mobilization of endothelial progenitor cells within the bone marrow, followed by recruitment in the blood and adhesion to the valve. Subsequently, recruited cells might undergo an epithelial to mesenchymal transdifferentiation within the valve (recapitulating development), followed by differentiation to interstitial cells that ultimately synthesize and remodel the ECM.

reconstruct the right ventricular outflow tract of adults undergoing the Ross procedure. ${ }^{29}$ According to the investigators, based on a one-year follow-up, seeded endothelial cells remained on the construct and were fully functional and the construct mechanical strength was maintained. There was no calcification and/or thrombogenesis. However, whether the seeded cells contributed to valve function is yet uncertain.

Despite promising results in animal experiments using decellularized xenograft scaffolds, translation to humans has been difficult. Clinical applications of implanted decellularized xenograft tissue heart valves have been largely unsuccessful. ${ }^{156}$ Histological examination of decellularized porcine aortic SynerGraft valves (Cryolife Inc.) implanted for 6 months in sheep without in-vitro preseeding suggested some growth of host cells on intact leaflets and showed a lack of calcification. ${ }^{32}$ Simon et al. used SynerGraft decellularized porcine heart valves as valve replacements in the right ventricular outflow tract during Ross procedures in children. The decellularized valves were not seeded or conditioned in a bioreactor before implant with the hope that the unseeded scaffold could attract endogenous cells. These valves had a high rate of failure; examination of failed valves revealed incomplete initial decellularization, lack of cell repopularization, lack of endothelialization, severe inflammation, fibrous sheath formation, calcification and severe degeneration of both leaflets and wall. ${ }^{156} \mathrm{~A}$ recent report showed a case with infiltration of a Synergraft valve by inflammatory cells (neutrophils and macrophages) at 5 weeks post implantation. ${ }^{140}$

\section{CHALLENGES FOR FUTURE TRANSLATION TO THE CLINIC}

Heart valve tissue engineering has exciting potential but many unanswered questions and challenges remain before human implantation can be considered. A successful tissue engineered valve must be vital, complex, dynamic, composed of specialized cells and ECM that remodel in response to changes in local mechanical forces, and have ongoing strength, flexibility, and durability, beginning at the instant of implantation and continuing indefinitely thereafter. A schema for the interrelationships among and challenges in tissue characterization for heart valve tissue engineering is summarized in Fig. 4. To provide an agenda for translating the notion of TEHVs from an extraordinarily interesting research curiosity to a clinically useful surgical tool, we discuss below both the major research goals-i.e., understanding mechanisms, defining animal models, developing biomarkers, developing assays/tools, defining surrogate and true endpoints-and the major clinical goalsi.e., characterizing and assuring quality tissue constructs, accommodating patient-to-patient heterogeneity in tissue remodeling, and predicting outcomes as early as possible.

Numerous steps must be surmounted in the laboratory before heart valve tissue engineered constructs can be made clinically useful. Typical biomaterial-tissue interactions in medical devices, such as thrombosis, infection, and inflammatory interactions, will have to be acceptable. Another important consideration is whether calcification, the major pathologic process in bioprosthetic valve degeneration, 
TABLE 5. Critical challenges to clinical translation of heart valve tissue engineering.

\begin{tabular}{lr}
\hline \multicolumn{1}{c}{ Challenges } & Strategy for translation \\
\hline $\begin{array}{l}\text { TEHV components and function are complex, heterogeneous and } \\
\text { dynamic }\end{array}$ & $\begin{array}{c}\text { Develop guidelines for the pre-implantation characterization of TEHV } \\
\text { structure, function and quality }\end{array}$ \\
$\begin{array}{l}\text { TEHV function depends upon patient response to implantation and } \\
\text { integration with the recipient's tissues more than conventional } \\
\text { valve replacement }\end{array}$ & $\begin{array}{r}\text { Identify/validate biomarkers predictive of implant success/failure and } \\
\text { caple of non-invasive in-vivo monitoring }\end{array}$ \\
$\begin{array}{l}\text { Individuals differ in the speed and effectiveness of their tissue } \\
\text { remodeling }\end{array}$ & $\begin{array}{c}\text { Assess/control patient variability in tissue remodeling capability } \\
\text { reliably predict human outcomes }\end{array}$ \\
$\begin{array}{l}\text { Remodeling processes after implantation may release or change } \\
\text { seeded cells and recruit host cells }\end{array}$ & $\begin{array}{r}\text { Validate suitable animal models that will test key biological } \\
\text { processes and correlate with human outcomes } \\
\text { Develop tools to monitor the fate of transplanted and endogenous } \\
\text { cells (location, function, viability, phenotype) }\end{array}$ \\
\hline
\end{tabular}

will be problematic. Evidence suggests that calcification may not be a major problem as long as polymer or other scaffold is resorbed and/or not intrinsically mineralizable, the interstitial cells are viable, and the ECM is capable of remodeling.

While studies using animal models such as sheep are promising, further detailed studies will be needed in these models, other animal models, and in humans. There is considerable controversy over to what extent results from available animal models translate directly to humans and the most suitable animal model for testing tissue-engineered valves has not yet been determined. Sheep for example, produce an exuberant fibrotic response to cardiovascular implants; valves implanted in sheep generally overgrow more rapidly with fibrotic tissue than they do in humans, and likely overestimate tissue remodeling relative to humans. ${ }^{144}$ Owing to immunologic considerations, the choice of an animal model for preclinical testing for allogenic or xenogeneic cell-based therapies presents unique challenges.

A key consideration is that currently available heart valve replacements have predictable behavior in many recipients whereas in-vivo remodeling of tissue engineered heart valves will likely display considerable variability

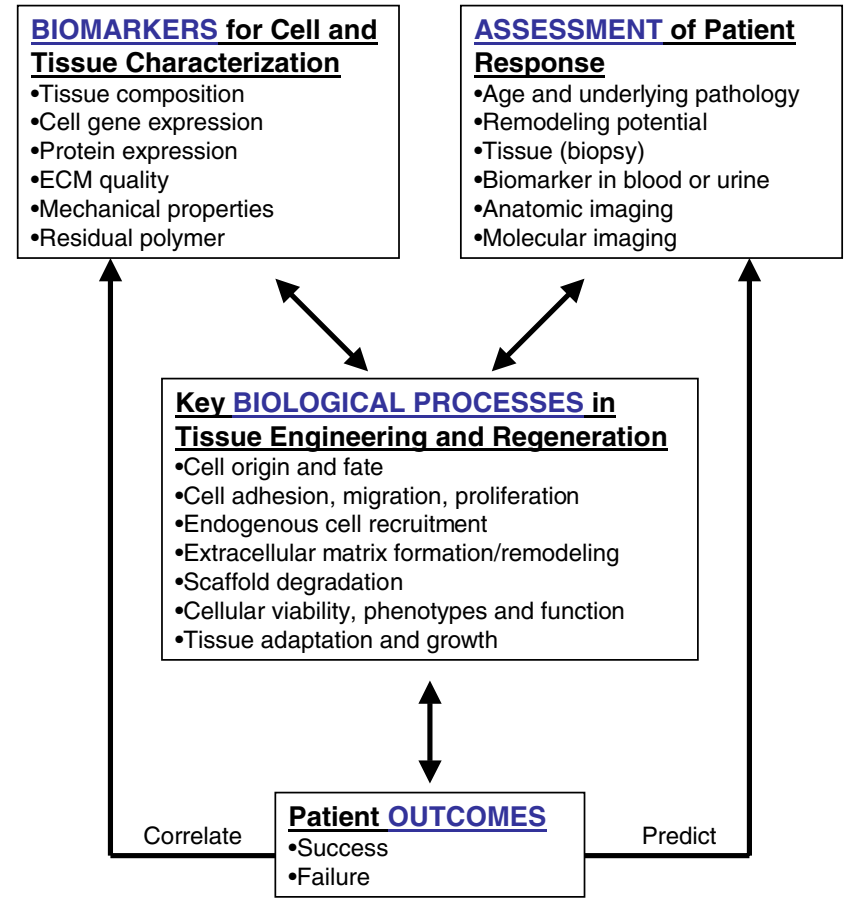

Research Goals

- Understand mechanisms

-Develop biomarkers

-Develop assays/tools

-Define surrogate endpoints

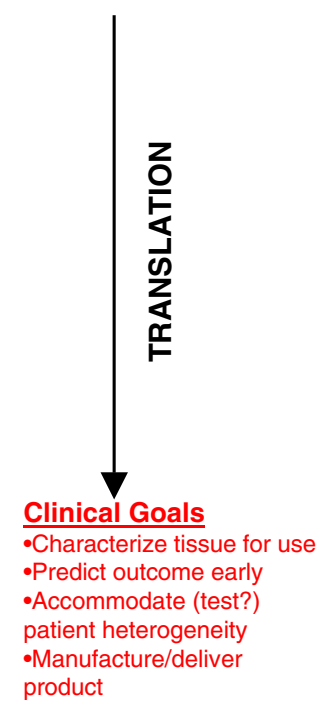

FIGURE 4. Paradigm for translating research in heart valve tissue engineering from the laboratory to the clinic. Biomarkers for cell and tissue characterization in conjunction with structural, chemical and molecular information obtained via in-vitro and invivo models are necessary for understanding key biological processes in tissue engineering and regenerative medicine. These concepts and data can be used to predict and measure patient success and failure. Data from clinical experience further informs the development of appropriate biomarkers, which may result in reassessment of the appropriate characterization parameters. 


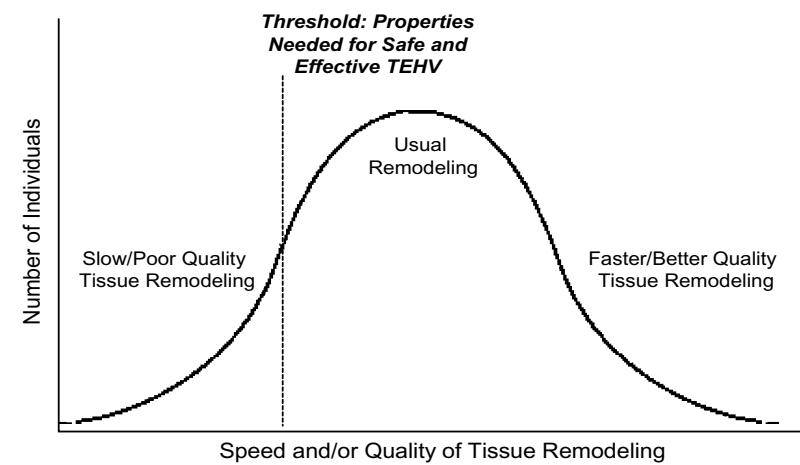

FIGURE 5. A hypothesis for inter-individual variability in tissue remodeling. While most individuals will remodel tissue with a usual speed and quality of remodeling, some people will display slow and poor quality of remodeling while others will show fast and better quality of remodeling. Inadequate remodeling could lead to implant failure and its consequences for the patient. The threshold of properties needed for tissue engineered heart valves and the means of conducting postimplantation surveillance of the patient and graft need to consider this variability. Success or failure may be followed and predicted non-invasively.

among patients, owing to heterogeneity among individuals in physiological tissue remodeling potential. As the field of tissue engineering evolves it may become important to apply principles analogous to those of pharmacogenetics, a field which seeks to understand the role of genetics in inter-individual variation in drug metabolism. ${ }^{179} \mathrm{Sim}$ ply stated, some patients might not appropriately remodel their tissue-engineered valves, and this could lead to failure (Fig. 5). This could be a result of mutations or polymorphisms in key proteins central to remodeling. ${ }^{11,24,38,91}$ Indeed, as implants have become more interactive and integrative with the host tissues, there has arisen a corresponding need to understand and potentially control human variation in different facets of biomaterial-tissue interaction and the healing process. To accommodate TEHVs, the usual mechanism for demonstrating pre-clinical safety and efficacy of medical devices and biologics may need to be altered due to unpredictability of the engineered tissue with the recipient's native tissue.

To understand, monitor, and potentially control patientto-patient differences in wound healing and tissue remodeling capability in-vivo, biomarkers that predict implant outcomes must be identified. Conventional and innovative invasive and/or non-invasive anatomic and functional imaging modalities will certainly be important tools to assess success and failure. Specific molecular biomarkers may be identified and validated by assessing tissue healing and remodeling during in-vitro and in-vivo experiments; suitable biomarkers will need to be followed in-vivo, possibly via chemical assays in the serum or urine or via molecular imaging. Key targets for characterizing tissue-engineered constructs include tissue composition, cellular gene expression and phenotype, ECM, key effectors of tissue remodeling and tissue quality. For example, researchers are currently working to identify serum-specific biomarkers of ECM remodeling in disease such as MMPs in acute coronary syndromes,${ }^{4,42}$ and urine-based biomarkers for cancers of the breast, ${ }^{39,136}$ bladder, ${ }^{49,175}$ and prostate.$^{55}$ These biomarkers should correlate directly with success and failure in order to generate surrogate endpoints, namely outcome measurements (such as laboratory assays or imaging results) that substitute for but reflect the mechanism of a significant clinical event or characteristic (such as regurgitation, stenosis, thromboembolism, calcification, infection, or death). Validated surrogate end points could be assessed in an individual patient, in order to predict outcome as early as possible in the patient's course and influence necessary changes in management.

The potential for molecular imaging is particularly exciting in this regard; it requires the identification of a molecular target, selection of a ligand that binds the target, selection of an appropriate imaging system, and synthesis of a molecular imaging agent to detect the desired target. ${ }^{8,44,57,62,63} \mathrm{In}$ vivo molecular imaging has been used to demonstrate key enzymatic and cellular events in atherosclerosis and thrombosis. For example, imaging studies on inflammatory markers such as proteases (cathepsins and MMPs), activated macrophages (expressing iron oxide), and activated endothelium (intercellular and vascular adhesion molecules) have been performed in atherosclerotic mice. ${ }^{19,24}$ Molecular imaging can probe polymorphisms of ECM gene expression in-vivo in models of cardiovascular disease, ${ }^{12,105}$ and can potentially be translated to perform real-time invivo characterization of scaffold matrices (either seeded or with the potential of attracting endogenous cells) implanted in animal models. Other imaging modalities such as optical coherence tomography (OCT $)^{15,47}$ and intravascular ultrasound (IVUS) ${ }^{111}$ have been used to assess collagen content of coronary atherosclerotic plaque; allowing realtime in-vivo analysis without tissue sampling. Such imaging modalities may prove useful in assessing tissue remodeling for heart valve tissue engineering applications.

Another important laboratory consideration for seeded scaffolds is the origin of the cells seeded in-vitro and whether the seeded cells remain viable and attached to the scaffold following in-vivo implantation. In the absence of in-vitro cell labeling, it is not possible to ascertain the fate of preseeded cells and the precise origin of the cellular phenotypes observed in the explanted tissue engineered valves. Molecular imaging could be utilized to track the presence, migration, proliferation, and function of bone marrow derived progenitor cells used to seed scaffolds both in-vitro and in-vivo. ${ }^{62,63}$ Moreover, molecular resonance imaging (MRI) of magnetically labeled mesenchymal stem cells injected into porcine myocardium has been performed in-vivo ${ }^{51}$ a technique which can potentially be expanded to study magnetically labeled endothelial and mesenchymal progenitor cells seeded on a scaffold and implanted into an 
animal or human model. In future experiments, endothelial progenitor and mesenchymal stem cells might be labeled during the in-vitro stage and then analyzed using molecular imaging to ensure that they differentiate into appropriate cell lineages and that they remain functional and attached to the scaffold over time.

There is a need to develop clinical guidelines that specify how to characterize the safety, efficacy, and quality of a tissue engineered product before it can be implanted in humans. Demonstration of long-term efficacy (implantability, functionality, long-term performance) and safety (biocompatibility, durability, modes of failure, ease of monitoring) of these valves in humans will be a particular challenge. Risk/benefit relationships of engineered tissue may be less predictable than those of accepted technology. Since contemporary heart valve replacements have considerable success in most situations (not withstanding the limitations, and except in pediatrics), acceptance of tissue engineering by the surgical community may be slow. It has been suggested that surgeons will consider the use of a tissue-engineered valve in a patient beyond appropriately controlled clinical research only after the 15-year lifetime of conventional valve substitutes can be exceeded with a high degree of certainty. ${ }^{128}$

Another key need is the development of sciencebased approaches to the characterization of fabricated/manufactured engineered tissue products in general and heart valves in particular. These will likely include measurement of mechanical properties of the scaffold and the tissue-scaffold complex, characterization of the dynamic cell phenotypes and ECM components, and the evolution of the final manufactured product, including shelf-life, stability, and shipping considerations.

\section{CONCLUSIONS}

The goal of heart valve tissue engineering is to regenerate a functional structure containing endothelial and interstitial cells capable of continuously remodeling the ECM that functions structurally and biomechanically as a valve leaflet. Despite an exciting potential for tissue engineered heart valves, significant technical barriers must be overcome before widespread clinical application can be envisioned. Further success toward a clinically useful tissue engineered heart valve will be dependent upon additional advances in biodegradable polymers, stem cell manipulation, strategies for recreating the ECM, understanding how to harvest the potential of endogenous recruitment of cells, and techniques to non-invasively assess the speed and quality of tissue healing and remodeling. This need is likely to engender a host of novel testing strategies and methods, which will include in-vitro safety studies, ex-vivo performance characterization in functional testing devices akin to bioreactors, and in-vivo preclinical studies.

\section{NOTE ADDED IN PROOF}

Several studies relevant to and that became available during final production of this manuscript may interest readers.

Visconti, R.P., Y. Ebihara, A.C. LaRue, P.A. Fleming, T.C. McQuinn, M. Masuya, H. Minamiguchi, R.R. Markwald, M. Ogawa, and C.J. Drake. An invivo analysis of hematopoietic stem cell potential: hematopoietic origin of cardiac valve interstitial cells. Circ. Res. 98:690-696, 2006.

To test the hypothesis that hematopoietic stem cells (HSC) may be a source of adult valve interstitial cells, single lineage-negative (Lin-), c-kit(+), Sca-l(+), CD34cells from the bone marrow of mice that ubiquitously express enhanced green fluorescent protein (EGFP) were transplanted into a lethally irradiated congenic non-EGFP mouse. Histological analyses of valve tissue from clonally engrafted recipient mice revealed the presence of numerous EGFP + cells within host valves, some of which exhibited synthetic properties characteristic of fibroblasts (expression of mRNA for procollagen 1 alpha 1). The cells were shown to be the result of HSC-derived cell differentiation and not fusion with host somatic cells. Together, these findings demonstrate a contribution by HSCs to the adult valve interstitial cell population in mice.

Cao, F., S. Lin, X. Xie, P. Ray, M. Patel, X. Zhang, M. Drukker, S.J. Dylla, A.J. Connolly, X. Chen, I.L. Weissman, S.S. Gambhir, and J.C. Wu. In vivo visualization of embryonic stem cell survival, proliferation, and migration after cardiac delivery. Circulation 113:10051014, 2006.

As discussed in the body of the present manuscript, monitoring the trafficking and function of stem cells in vivo remains problematic owing to limitations of conventional histological assays and imaging modalities. A recent study demonstrated a method by which embryonic stem (ES) cells could be stably transduced with a lentiviral vector carrying a novel triple-fusion (TF) reporter gene, tracked by positron emission tomography, and monitored for survival, proliferation, and migration. This imaging platform should have broad applications for basic research and clinical studies on stem cell therapy.

Kiernan, T.J. Endothelial progenitor cells in 2006 where are we now? Cardiovasc. Pathol. 15:236-239, 2006.

A recent brief review of the current status of endothelial progenitor cells (EPCs), including their role as biomarkers and potential therapeutic applications, may be useful to the reader of the present manuscript. The authors emphasize critical questions relating to the characterization of the biological phenotype of "true" EPCs and the mechanisms of interaction of EPCs with resident cells of the vascular wall. 


\section{REFERENCES}

${ }^{1}$ Aikawa, E., P. Whittaker, M. Farber, K. Mendelson, R. Padera, and F. Schoen. Human semilunar cardiac valve remodeling by activated cells from fetus to adult: Implications for postnatal adaptation, valve pathology and tissue engineering. Circulation 113:1344-1352, 2006.

${ }^{2}$ Anderson, D. G., J. A. Burdick, and R. Langer. Materials science. Smart biomaterials. Science 305:1923-1924, 2004.

${ }^{3}$ Aoki, J., P. W. Serruys, H. van Beusekom, A. T. Ong, E. P. McFadden, G. Sianos, W. J. van der Giessen, E. Regar, P. J. de Feyter, H. R. Davis, S. Rowland, and M. J. Kutryk. Endothelial progenitor cell capture by stents coated with antibody against CD34: the HEALING-FIM (Healthy Endothelial Accelerated Lining Inhibits Neointimal Growth-First In Man) Registry. $J$. Am. Coll. Cardiol. 45:1574-1579, 2005.

${ }^{4}$ Apple, F. S., A. H. Wu, J. Mair, J. Ravkilde, M. Panteghini, J. Tate, F. Pagani, R. H. Christenson, M. Mockel, O. Danne, A. S. Jaffe, and the Committee on Standardization of Markers of Cardiac Damage of the IFCC. Future biomarkers for detection of ischemia and risk stratification in acute coronary syndrome. Clin. Chem. 51:810-824, 2005.

${ }^{5}$ Armstrong, E. J., and J. Bischoff. Heart valve development: Endothelial cell signaling and differentiation. Circ. Res. 95:459470, 2004.

${ }^{6}$ Badylak, S. F. Regenerative medicine approach to heart valve replacement. Circulation 111:2715-2716, 2005.

${ }^{7}$ Badylak, S. F., R. Record, K. Lindberg, J. Hodde, and K. Park. Small intestinal submucosa: a substrate for in vitro cell growth. J. Biomater. Sci. Polym. 9:863-878, 1998.

${ }^{8}$ Basilion, J. P., S. Yeon, and R. Botnar. Magnetic resonance imaging: utility as a molecular imaging modality. Curr. Top Dev. Biol. 70:1-33, 2005.

${ }^{9}$ Beis, D., T. Bartman, S. W. Jin, I. C. Scott, L. A. D’Amico, E. A. Ober, H. Verkade, J. Frantsve, H. A. Field, A. Wehman, H. Baier, A. Tallafuss, L. Bally-Cuif, J. N. Chen, D. Y. Stainier, and B. Jungblut. Genetic and cellular analyses of zebrafish atrioventricular cushion and valve development. Development 132:4193-4204, 2005.

${ }^{10}$ Bertipaglia, B., F. Ortolani, L. Petrelli, G. Gerosa, M. Spina, P. Pauletto, D. Casarotto, M. Marchini, and S. Sartore. Vitalitate Exornatum Succedaneum Aorticum Labore Ingenioso Obtenibitur Project. Cell characterization of porcine aortic valve and decellularized leaflets repopulated with aortic valve interstitial cells: the VESALIO Project (Vitalitate Exornatum Succedaneum Aorticum Labore Ingenioso Obtenibitur). Ann. Thorac. Surg. 75:1274-1282, 2003.

${ }^{11}$ Blom, I. E., A. J. van Dijk, R. A. de Weger, M. G. Tilanus, and R. Goldschmeding. Identification of human ccn2 (connective tissue growth factor) promoter polymorphisms. Mol. Pathol. 54:192-196, 2001

${ }^{12}$ Boecker, W., O. Y. Bernecker, J. C. Wu, X. Zhu, T. Sawa, L. Grazette, A. Rosenzweig, F. del Monte, U. Schmidt, and R. J. Hajjar. Cardiac-specific gene expression facilitated by an enhanced myosin light chain promoter. Mol. Imaging 3:69-75, 2004.

${ }^{13}$ Borschel, G. H., Y. C. Huang, S. Calve, E. M. Arruda, J. B. Lynch, D. E. Dow, W. M. Kuzon, R. G. Dennis, and D. L. Brown. Tissue engineering of recellularized small-diameter vascular grafts. Tissue Eng. 11:778-786, 2005.

${ }^{14}$ Breuer, C. K., B. A. Mettler, T. Anthony, V. L. Sales, F. J. Schoen, J. E. Mayer. Application of tissue-engineering principles toward the development of a semilunar heart valve substitute. Tissue Eng. 10:1725-1736, 2004.
${ }^{15}$ Brezinski, M. E. Optical coherence tomography for identifying unstable coronary plaque. Int. J. Cardiol. 107:159-170, 2006.

${ }^{16}$ Butcher, J. T., and R. M. Nerem. Porcine aortic valve interstitial cells in three-dimensional culture: comparison of phenotype with aortic smooth muscle cells. J. Heart Valve Dis. 13:478485, 2004.

${ }^{17}$ Butcher, J. T., A. M. Penrod, A. J. Garcia, and R. M. Nerem. Unique morphology and focal adhesion development of valvular endothelial cells in static and fluid flow environments. $\mathrm{Ar}$ terioscler. Thromb. Vasc. Biol. 24:1429-1434, 2004.

${ }^{18}$ Ceradini, D. J., and G. C. Gurtner. Homing to hypoxia: HIF-1 as a mediator of progenitor cell recruitment to injured tissue. Trends Cardiovasc Med. 15:57-63, 2005.

${ }^{19}$ Chen, J., C. H. Tung, U. Mahmood, V. Ntziachristos, R. Gyurko, M. C. Fishman, P. L. Huang, and R. Weissleder. In-vivo imaging of proteolytic activity in atherosclerosis. Circulation 105:27662771, 2002.

${ }^{20}$ Courtney, T., M. S. Sacks, J. Stankus, J. Guan, and W. R. Wagner. Analysis and design of tissue engineered scaffolds that mimic soft tissue mechanical anisotropy. Biomat. 27:36313638,2006

${ }^{21}$ Davies, P. F., A. G. Passerini, and C. A. Simmons. Aortic valve: turning over a new leaf(let) in endothelial phenotypic heterogeneity. Arterioscler Thromb. Vasc. Biol. 24:1331-1333, 2004.

${ }^{22}$ Dawn, B., and R. Bolli. Adult bone marrow-derived cells: Regenerative potential, plasticity, and tissue commitment. Basic Res. Cardiol. 100:494-503, 2005.

${ }^{23}$ Deb, A., S. H. Wang, K. Skelding, D. Miller, D. Simper, and N. Caplice. Bone marrow-derived myofibroblasts are present in adult human heart valves. J. Heart Valve Dis. 14:674-678, 2005.

${ }^{24}$ Deguchi, J.-O., E. Aikawa, P. Libby, J. R. Vachon, M. Inada, S. M. Krane, P. Whittaker, and M. Aikawa. Matrix metalloproteinase-13/collagenase-3 deletion promotes collagen accumulation and organization in mouse atherosclerotic plaques. Circulation 112:2708-2715, 2005.

${ }^{25}$ Della Rocca, F., S. Sartore, D. Guidolin, B. Bertiplaglia, G. Gerosa, D. Casarotto, and P. Pauletto. Cell composition of the human pulmonary valve: A comparative study with the aortic valve-The VESALIO project. Ann. Thorac. Surg. 70:1594$1600,2000$.

${ }^{26}$ Deutsch, M., J. Meinhart, T. Fischlein, P. Preiss, and P. Zilla. Clinical autologous in vitro endothelialization of infrainguinal ePTFE grafts in 100 patients: a 9-year experience. Surgery 126:847-855, 1999.

${ }^{27}$ Dimmeler, S., A. M. Zeiher, and M. D. Schneider. Unchain my heart: the scientific foundations of cardiac repair. J. Clin. Invest 115:572-583, 2005.

${ }^{28}$ Dohmen, P. M., F. Costa, S. V. Lopes, S. Yoshi, F. P. Souza, R. Vilani, M. B. Costa, and W. Konertz. Results of a decellularized porcine heart valve implanted into the juvenile sheep model. Heart Surg. Forum. 8:E100-E104, 2005.

${ }^{29}$ Dohmen, P. M., A. Lembcke, H. Hotz, D. Kivelitz, and W. F. Konertz. Ross operation with a tissue-engineered heart valve. Ann. Thorac. Surg. 74:1438-1442, 2002.

${ }^{30}$ Eisenberg, L. M., and R. R. Markwald. Molecular regulation of atrioventricular valvuloseptal morphogenesis. Circ. Res. 77:16, 1995.

${ }^{31}$ Eisenberg, L. M., R. Moreno, and R. R. Markwald. Multiple stem cell populations contribute to the formation of the myocardium. Ann. N.Y. Acad. Sci. 1047:38-49, 2005.

${ }^{32}$ Elkins, R. C., P. E. Dawson, S. Goldstein, S. P. Walsh, and K. S. Black. Decellularized human valve allografts. Ann. Thorac. Surg. 71:S428-S432, 2001. 
${ }^{33}$ Emsley, J. G., B. D. Mitchell, G. Kempermann, and J. D. Macklis. Adult neurogenesis and repair of the adult CNS with neural progenitors, and stem cells. Prog. Neurobiol. 75:321-341, 2005.

${ }^{34}$ Engelmayr, G. C., D. K. Hildebrand, F. W. Sutherland, J. E. Mayer, and M. S. Sacks. A novel bioreactor for the dynamic flexural stimulation of tissue engineered heart valve biomaterials. Biomaterials 24:2523-2532, 2003.

${ }^{35}$ Erez, E., K. R. Kanter, E. Isom, W. H. Williams, and V. K. Tam. Mitral valve replacement in children. J. Heart Valve Dis. 12:25-29, 2003.

${ }^{36}$ Eschenhagen, T., and W. H. Zimmermann. Engineering myocardial tissue. Circ. Res. 97:1220-1231, 2005.

${ }^{37}$ Eybl, E., M. Grimm, M. Grabenwoger, P. Bock, M. M. Muller, and E. Wolner. Endothelial cell lining of bioprosthetic heart valve materials. J. Thorac. Cardiovasc. Surg. 104:763-769, 1992.

${ }^{38}$ Fedak, P. W. M., D. S. Smookler, Z. Kassiri, N. Ohno, K. J. Leco, S. Verma, D. A. G. Mickle, K. L. Watson, C. V. Hojilla, W. Cruz, R. D. Weisel, R.-K. Li, and R. Khokha. TIMP-3 deficiency leads to dilated cardiomyopathy. Circulation 110:24012409, 2004.

${ }^{39}$ Fernandez, C. A., L. Yan, G. Louis, J. Yang, J. L. Kutok, and M. A. Moses. The matrix metalloproteinase-9/neutrophil gelatinase-associated lipocalin complex plays a role in breast tumor growth and is present in the urine of breast cancer patients. Clin. Cancer Res. 11:5390-5395, 2005.

${ }^{40}$ Frazier, O. H., R. T. Baldwin, S. G. Eskin, and J. M. Duncan. Immunochemical identification of human endothelial cells on the lining of a ventricular assist device. Tex Heart Inst. J. 20:7882, 1993.

${ }^{41}$ Freed, L. E., G. Vunjak-Novakovic, R. J. Biron, D. B. Eagles, D. C. Lesnoy, S. K. Barlow, and R. Langer. Biodegradable polymer scaffolds for tissue engineering. Biotechnology 12:689-693, 1994.

${ }^{42}$ Fukuda, D., K. Shimada, A. Tanaka, T. Kusuyama, H. Yamashita, S. Ehara, Y. Nakamura, T. Kawarabayashi, H. Iida, M. Yoshiyama, and J. Yoshikawa. Comparison of levels of serum matrix metalloproteinase- 9 in patients with acute myocardial infarction versus unstable angina pectoris versus stable angina pectoris. Am. J. Cardiol. 97:175-180, 2006.

${ }^{43}$ Garg, V., A. N. Muth, J. F. Ransom, M. K. Schluterman, R. Barnes, I. N. King, P. D. Grossfeld, and D. Srivastava. Mutations in NOTCH1 cause aortic valve disease. Nature 437:270-274, 2005.

${ }^{44}$ Genove, G., U. DeMarco, H. Xu, W. F. Goins, and E. T. Ahrens. A new transgene reporter for in vivo magnetic resonance imaging. Nat. Med. 11:450-454, 2005.

${ }^{45}$ George, J., A. Afek, A. Abashidze, H. Shmilovich, V. Deutsch, J. Kopolovich, H. Miller, and G. Keren. Transfer of endothelial progenitor and bone marrow cells influences atherosclerotic plaque size and composition in Apolipoprotein E knockout mice. Arterioscler. Thromb. Vasc. Biol. 25:2636-2641, 2005.

${ }^{46}$ Giannoudis, P. V., and I. Pountos. Tissue regeneration: The past, the present and the future. Injury 36(Suppl.):S2-S5, 2005.

${ }^{47}$ Giattina, S. D., B. K. Courtney, P. R. Herz, M. Harman, S. Shortkroff, D. L. Stamper, B. Liu, J. G. Fujimoto, and M. E. Brezinski. Assessment of coronary plaque collagen with polarization sensitive optical coherence tomography (PS-OCT). Int. J. Cardiol. 107:400-409, 2006.

${ }^{48}$ Grayson, A. C., G. Voskerician, A. Lynn, J. M. Anderson, M. J. Cima, and R. Langer. Differential degradation rates in vivo and in vitro of biocompatible poly(lactic acid) and poly(glycolic acid) homo- and co-polymers for a polymeric drug-delivery microchip. J. Biomater. Sci. Polym. Ed. 15:1281-1304, 2004.

${ }^{49}$ Grossman, H. B., M. Soloway, E. Messing, G. Katz, B. Stein, V. Kassabian, and Y. Shen. Surveillance for recurrent bladder cancer using a point-of-care proteomic assay. JAMA 295:299305, 2006.

${ }^{50}$ Hammermeister, K., G. K. Sethi, W. G. Henderson, F. L. Grover, C. Oprian, and S. H. Rahimtoola. Outcomes 15 years after valve replacement with a mechanical versus a bioprosthetic valve: final report of the Veterans Affairs randomized trial. J. Am. Coll. Cardiol. 36:1152-1158, 2000.

${ }^{51}$ Hill, J. M., A. J. Dick, V. K. Raman, R. B. Thompson, Z. X. Yu, K. A. Hinds, B. S. Pessanha, M. A. Guttman, T. R. Varney, B. J. Martin, C. E. Dunbar, E. R. McVeigh, and R. J. Lederman. Serial cardiac magnetic resonance imaging of injected mesenchymal stem cells. Circulation 108:1009-1014, 2003.

${ }^{52}$ Hoerstrup, S. P., R. Sodian, S. Daebritz, J. Wang, E. A. Bacha, D. P. Martin, A. M. Moran, K. J. Guleserian, J. S. Sperling, S. Kaushal, J. P. Vacanti, F. J. Schoen, and J. E. Mayer. Functional living trileaflet heart valves grown in vitro. Circulation 102:SIII-44-SIII-49, 2000.

${ }^{53}$ Hollister, S. J. Porous scaffold design for tissue engineering. Nat. Mater. 4:518-524, 2005.

${ }^{54}$ Hopkins, R. A. Tissue engineering of heart valves: decellularized valve scaffolds. Circulation 111:2712-2714, 2005.

${ }^{55}$ Hoque, M. O., O. Topaloglu, S. Begum, R. Henrique, E. Rosenbaum, W. Van Criekinge, W. H. Westra, and D. Sidransky. Quantitative methylation-specific polymerase chain reaction gene patterns in urine sediment distinguish prostate cancer patients from control subjects. J. Clin. Oncol. 23:6569-6575, 2005.

${ }^{56}$ Hristov, M., W. Erl, and P. C. Weber. Endothelial progenitor cells: mobilization, differentiation, and homing. Arterioscler. Thromb. Vasc. Biol. 23:1185-1189, 2003.

${ }^{57}$ Ichikawa, T., D. Hogemann, Y. Saeki, E. Tyminski, K. Terada, R. Weissleder, E. A. Chiocca, and J. P. Basilion. MRI of transgene expression: correlation to therapeutic gene expression. Neoplasia 4:523-530, 2002.

${ }^{58}$ Isenberg, B. C., C. Williams, and R. T. Tranquillo. Smalldiameter artificial arteries engineered in vitro. Circ. Res. 98:25$35,2006$.

${ }^{59}$ Ishihara, T., V. J. Ferrans, M. Jones, S. W. Boyce, and W. C. Roberts. Occurrence and significance of endothelial cells in implanted porcine bioprosthetic valves. Am.J. Cardiol. 48:443454, 1981.

${ }^{60}$ Iwai, S., Y. Sawa, H. Ichikawa, S. Taketani, E. Uchimura, G. Chen, M. Hara, J. Miyake, and H. Matsuda. Biodegradable polymer with collagen microsponge serves as a new bioengineered cardiovascular prosthesis. J. Thorac. Cardiovasc. Surg. 128:472-479, 2004

${ }^{61}$ Iwami, Y., H. Masuda, and T. Asahara. Endothelial progenitor cells: past, state of the art, and future. J. Cell Mol. Med. 8:488497, 2004.

${ }^{62}$ Jaffer, F. A., and R. Weissleder. Seeing within: molecular imaging of the cardiovascular system. Circ. Res. 94:433-445, 2004.

${ }^{63}$ Jaffer, F. A., and R. Weissleder. Molecular imaging in the clinical arena. J. Am. Med. Assoc. 293:855-862, 2005.

${ }^{64}$ Jamieson, W. R., O. von Lipinski, R. T. Miyagishima, L. H. Burr, M. T. Janusz, H. Ling, G. J. Fradet, F. Chan, and E. Germann. Performance of bioprostheses and mechanical prostheses assessed by composites of valve-related complications to 15 years after mitral valve replacement. J. Thorac. Cardiovasc. Surg. 129:1301-1308, 2005.

${ }^{65}$ Jiang, Y., B. N. Jahagirdar, R. L. Reinhardt, R. E. Schwartz, C. D. Keene, X. R. Ortiz-Gonzalez, M. Reyes, T. Lenvik, T. Lund, 
M. Blackstad, J. Du, S. Aldrich, A. Lisberg, W. C. Low, D. A. Largaespada, and C. M. Verfaillie. Pluripotency of mesenchymal stem cells derived from adult marrow. Nature 418:41-49, 2002.

${ }^{66}$ Jockenhoevel, S., G. Zund, S. P. Hoerstrup, K. Chalabi, J. S. Sachweh, L. Demircan, B. J. Messmer, and M. Turina. Fibrin gel-advantages of a new scaffold in cardiovascular tissue engineering. Eur. J. Cardiothorac. Surg. 19:424-430, 2001.

${ }^{67}$ Jonas, R. A. The Ross procedure is not the procedure of choice for the teenager requiring aortic valve replacement. Semin. Thorac. Cardiovasc. Surg. Pediatr. Card Surg. Annu. 176-180, 2005.

${ }^{68}$ Kanter, K. R., J. M. Budde, W. J. Parks, V. K. Tam, S. Sharma, W. H. Williams, and D. A. Fyfe. One hundred pulmonary valve replacements in children after relief of right ventricular outflow tract obstruction. Ann. Thorac. Surg. 73:1801-1806, 2002.

${ }^{69}$ Karageorgiou, V. and D. Kaplan. Porosity of 3D biomaterial scaffolds and osteogenesis. Biomaterials 26:5474-5491, 2005.

${ }^{70}$ Kaushal, S., G. E. Amiel, K. J. Guleserian, O. M. Shapira, T. Perry, F. W. Sutherland, E. Rabkin, A. M. Moran, F. J. Schoen, A. Atala, S. Soker, J. Bischoff, and J. E. Mayer. Functional small-diameter neovessels created using endothelial progenitor cells expanded ex vivo. Nature Med. 7:1035-1040, 2001.

${ }^{71}$ Kohn, J., S. Abramson, and R. Langer. Bioresorbable and bioerodible materials. In: Biomaterials Science: An Introduction to Materials in Medicine, 2nd Ed., edited by B. D. Ratner, A. S. Hoffman, F. J. Schoen, and J. E. Lemons. Orlando: Academic Press, 2004.

${ }^{72}$ Konertz, W., P. M. Dohmen, J. Liu, S. Beholz, S. Dushe, S. Posner, A. Lembcke, and W. Erdbrugger. Hemodynamic characteristics of the Matrix P decellularized xenograft for pulmonary valve replacement during the Ross operation. J. Heart Valve Dis. 14:78-81, 2005.

${ }^{73}$ Kumar, V., N. Fausto, and A. Abbas. Robbins and Cotran Pathologic Basis of Disease, 7th Ed. Philadelphia: W. B. Saunders, 2004.

${ }^{74}$ Laflamme, M. A., and C. E. Murry. Regenerating the heart. Nature Biotech. 23:845-855, 2005.

${ }^{75}$ Lahann, J., S. Mitragotri, T. N. Tran, H. Kaido, J. Sundaram, I. S. Choi, S. Hoffer, G. A. Somorjai, and R. Langer. A reversibly switching surface. Science 299:371-374, 2003.

${ }^{76}$ Langer, R., and D. A. Tirrell. Designing materials for biology and medicine. Nature 428:487-492, 2004.

${ }^{77}$ Langer, R., and J. P. Vacanti. Tissue engineering. Science 260:920-926, 1993.

${ }^{78}$ Lee, Y. M., J. J. Cope, G. E. Ackermann, K. Goishi, E. J. Armstrong, B. H. Paw, and J. Bischoff. Vascular endothelial growth factor receptor signaling is required for cardiac valve formation in zebrafish. Dev. Dyn. 235:29-37, 2006.

${ }^{79}$ Lendlein, A., and R. Langer. Biodegradable, elastic shapememory polymers for potential biomedical applications. Science 296:1673-1676, 2002.

${ }^{80}$ Leor, J., Y. Amsalem, and S. Cohen. Cells, scaffolds, and molecules for myocardial tissue engineering. Pharmacol. Therapeut. 105:151-163, 2005.

${ }^{81}$ Leri, A., J. Kajstura, and P. Anversa. Cardiac stem cells and mechanisms of myocardial regeneration. Physiol. Rev. 85:1373-1416, 2005.

${ }^{82}$ Liu, C., K. A. Nath, Z. S. Katusic, and N. M. Caplice. Smooth muscle progenitor cells in vascular disease. Trends Cardiovasc. Med. 14:288-293, 2004.

${ }^{83}$ Liu, X., and P. X. Ma. Polymeric scaffolds for bone tissue engineering. Ann. Biomed. Eng. 32:477-486, 2004.
${ }^{84}$ Lutolf, M. P., and J. A. Hubbell. Synthetic biomaterials as instructive extracellular microenvironments for morphogenesis in tissue engineering. Nat. Biotechnol. 23:47-55, 2005.

${ }^{85}$ Mann, B. K., A. S. Gobin, A. T. Tsai, R. H. Schmedlen, and J. L. West. Smooth muscle cell growth in photopolymerized hydrogels with cell adhesive and proteolytically degradable domains: synthetic ECM analogs for tissue engineering. Biomaterials 22:3045-3051, 2001.

${ }^{86}$ Mareschi, K., I. Ferrero, D. Rustichelli, S. Aschero, L. Gammaitoni, M. Aglietta, E. Madon, and F. Fagioli. Expansion of mesenchymal stem cells isolated from pediatric and adult donor bone marrow. J. Cell Biochem. 97:744-754, 2006.

${ }^{87}$ Marron, K., M. H. Yacoub, J. M. Polak, M. N. Sheppard, D. Fagan, B. F. Whitehead, M. R. de Leval, R. H. Anderson, and J. Wharton. Innervation of human atrioventricular and arterial valves. Circulation 94:368-375, 1996.

${ }^{88}$ Masters, K. S., D. N. Shah, L. A. Leinwand, and K. S. Anseth. Crosslinked hyaluronan scaffolds as a biologically active carrier for valvular interstitial cells. Biomaterials 26:2517-2525, 2005.

${ }^{89}$ Matheny, R. G., M. L. Hutchison, P. E. Dryden, M. D. Hiles, and C. J. Shaar. Porcine small intestine submucosa as a pulmonary valve leaflet substitute. J. Heart Valve Dis. 9:769-774, 2000.

${ }^{90}$ Mauney, J. R., V. Volloch, and D. L. Kaplan. Role of adult mesenchymal stem cells in bone tissue engineering applications: current status and future prospects. Tissue Eng. 11:787-802, 2005.

${ }^{91}$ McBrearty, B. A., L. D. Clark, X-M, Zhang, E. P. Blankenhorn, and E. Heber-Katz. Genetic analysis of a mammalian woundhealing trait. Proc. Natl. Acad. Sci. USA 95:11792-11797, 1998.

${ }^{92}$ Merryman, W. D., G. C. Engelmayr, J. Liao, and M. S. Sacks. Defining biomechanical endpoints for tissue engineered heart valve leaflets from native leaflet properties. Prog. Ped. Card. (in press).

${ }^{93}$ Merryman, W. D., H. D. Lukoff, R. A. Hopkins, and M. S. Sacks. Aortic valve interstitial cell phenotype and biosynthesis: synergistic effects of cyclic tension and TGF- $\beta 1$. Proceedings of BIO2006. ASME Summer Bioengineering Conference, 2006.

${ }^{94}$ Merryman, W. D., I. Youn, H. D. Lukoff, P. M. Krueger, F. Guilak, R. A. Hopkins, and M. S. Sacks. Correlation between heart valve interstitial cell stiffness and transvalvular pressure: implications for collagen biosynthesis. Am. J. Physiol. Heart Circ. Physiol. 290:H224-H231, 2006.

${ }^{95}$ Mitchell, R. N., R. A. Jonas, and F. J. Schoen. Pathology of explanted cryopreserved allograft heart valves: comparison with aortic valves from orthotopic heart transplants. J. Thorac. Cardiovasc. Surg. 115:118-127, 1998.

${ }^{96}$ Mol, A., N. J. Driessen, M. C. Rutten, S. P. Hoerstrup, C. V. Bouten, and F. P. Baaijens. Tissue engineering of human heart valve leaflets: a novel bioreactor for a strain-based conditioning approach. Ann. Biomed. Eng. 33:1778-1788, 2005.

${ }^{97}$ Mol, A., M. I. van Lieshout, C. G. Dam-de Veen, S. Neuenschwander, S. P. Hoerstrup, F. P. Baaijens, and C. V. Bouten. Fibrin as a cell carrier in cardiovascular tissue engineering applications. Biomaterials 26:3113-3121, 2005.

${ }^{98}$ Mouquet, F., O. Pfister, M. Jain, A. Oikonomopoulos, S. Ngoy, R. Summer, A. Fine, and R. Liao. Restoration of cardiac progenitor cells after myocardial infarction by self-proliferation and selective homing of bone marrow-derived stem cells. Circ Res. 97:1090-1092, 2005.

${ }^{99}$ Mulholland, D. L., and A. I. Gotlieb. Cell biology of valvular interstitial cells. Can. J. Cardiol. 12:231-236, 1996. 
${ }^{100}$ Muschler, G. F., C. Nakamoto, and L. G. Griffith. Engineering principles of clinical cell-based tissue engineering. J. Bone Joint Surg. Am. 86A:1541-1558, 2004.

${ }^{101}$ Narita, Y., K. Hata, H. Kagami, A. Usui, M. Ueda, and Y. Ueda. Novel pulse duplicating bioreactor system for tissue-engineered vascular construct. Tissue Eng. 10:1224-1233, 2004.

${ }^{102}$ Nerem, R. M., and A. E. Ensley. The tissue engineering of blood vessels and the heart. Am. J. Transplant 4:36-42, 2004.

${ }^{103}$ Niklason, L. E., J. Gao, W. M. Abbott, K. K. Hirschi, S. Houser, R. Marini, and R. Langer. Functional arteries grown in vitro. Science 284:489-493, 1999.

${ }^{104}$ Nugent, H. M., and E. R. Edelman. Tissue engineering therapy for cardiovascular disease. Circ. Res. 92:1068-1078, 2003.

${ }^{105}$ Ogata, T., H. Shibamura, G. Tromp, M. Sinha, K. A. Goddard, N. Sakalihasan, R. Limet, G. L. MacKean, C. Arthur, T. Sueda, S. Land, and H. Kuivaniemi. Genetic analysis of polymorphisms in biologically relevant candidate genes in patients with abdominal aortic aneurysms. J. Vasc. Surg. 41:1036-1042, 2005.

${ }^{106}$ Olson, E. N. A decade of discoveries in cardiac biology. Nat. Med. 10:467-474, 2004

${ }^{107}$ Orlic, D., J. Kajstura, S. Chimenti, F. Limana, I. Jakoniuk, F. Quaini, B. Nadal-Ginard, D. M. Bodine, A. Leri, and P. Anversa. Mobilized bone marrow cells repair the infarcted heart, improving function and survival. Proc. Natl. Acad. Sci. 98:10344-10349, 2001.

${ }^{108}$ Ota, T., Y. Sawa, S. Iwai, T. Kitajima, Y. Ueda, C. Coppin, H. Matsuda, and Y. Okita. Fibronectin-hepatocyte growth factor enhances reendothelialization in tissue-engineered heart valve. Ann. Thorac. Surg. 80:1794-1801, 2005.

${ }^{109}$ Ott, I., U. Keller, M. Knoedler, K. S. Gotze, K. Doss, P. Fischer, K. Urlbauer, G. Debus, N. von Bubnoff, M. Rudelius, A. Schomig, C. Peschel, and R. A. Oostendorp. Endothelial-like cells expanded from CD34 + blood cells improve left ventricular function after experimental myocardial infarction. FASEB 19:992-994, 2005.

${ }^{110}$ Paranya, G., S. Vineberg, E. Dvorin, S. Kaushal, S. J. Roth, E. Rabkin, F. J. Schoen, and J. Bischoff. Aortic valve endothelial cells undergo TGF-beta-mediated and non-TGF-beta-mediated transdifferentiation in vitro. Am. J. Pathol. 159:1335-1343, 2001.

${ }^{111}$ Patel, N. A., D. L. Stamper, and M. E. Brezinski. Review of the ability of optical coherence tomography to characterize plaque, including a comparison with intravascular ultrasound. Cardiovasc. Intervent. Radiol. 28:1-9, 2005.

${ }^{112}$ Perry, T. E., S. Kaushal, F. W. Sutherland, K. J. Guleserian, J. Bischoff, M. Sacks, and J. E. Mayer. Bone marrow as a cell source for tissue engineering heart valves. Ann. Thorac. Surg. 75:761-767, 2003

${ }^{113}$ Pittenger, M. F., and B. J. Martin. Mesenchymal stem cells and their potential as cardiac therapeutics. Circ. Res. 95:9-20, 2004

${ }^{114}$ Poh, M., M. Boyer, A. Solan, S. L. Dahl, D. Pedrotty, S. S. Banik, J. A. McKee, R. Y. Klinger, C. M. Counter, and L. E. Niklason. Blood vessels engineered from human cells. Lancet 365:2122-2124, 2005.

${ }^{115}$ Pratt, A. B., F. E. Weber, H. G. Schmoekel, R. Muller, and J. A. Hubbell. Synthetic extracellular matrices for in situ tissue engineering. Biotechnol. Bioeng. 86:27-36, 2004.

${ }^{116}$ Prockop, D. J. Marrow stromal cells as stem cells for nonhematopoietic tissues. Science 276:71-74, 1997.

${ }^{117}$ Rabkin, E., M. Aikawa, J. R. Stone, Y. Fukumoto, P. Libby, and F. J. Schoen. Activated interstitial myofibroblasts express catabolic enzymes and mediate matrix remodeling in myxomatous heart valves. Circulation 104:2525-2532, 2001.
${ }^{118}$ Rabkin, E., S. P. Hoerstrup, M. Aikawa, J. E. Mayer, and F. J. Schoen. Evolution of cell phenotype and extracellular matrix in tissue-engineered heart valves during in vitro maturation and in vivo remodeling. J. Heart Valve Dis. 11:308-314, 2002.

${ }^{119}$ Rabkin, E., and F. J. Schoen. Cardiovascular tissue engineering. Cardiovasc. Pathol. 11:305-317, 2002.

${ }^{120}$ Rabkin-Aikawa, E., M. Aikawa, M. Farber, J. R. Kratz, G. Garcia-Cardena, N. T. Kouchoukos, M. B. Mitchell, R. A. Jonas, and F. J. Schoen. Clinical pulmonary autograft valves: pathologic evidence of adaptive remodeling in the aortic site. J. Thorac. Cardiovasc. Surg. 128:552-561, 2004.

${ }^{121}$ Rabkin-Aikawa, E., M. Farber, M. Aikawa, and F. J. Schoen. Dynamic and reversible changes of interstitial cell phenotype during remodeling of cardiac valves. J. Heart Valve Dis. 13:841-847, 2004.

${ }^{122}$ Rabkin-Aikawa, E., J. E. Mayer, and F. J. Schoen. Heart valve regeneration. Adv. Biochem. Eng. Biotechnol. 94:141179,2005

${ }^{123}$ Radisic, M., H. Park, H. Shing, T. Consi, F. J. Schoen, R. Langer, L. E. Freed, and G. Vunjak-Novakovic. Functional assembly of engineered myocardium by electrical stimulation of cardiac myocytes cultured on scaffolds. Proc. Natl. Acad. Sci. USA 101:18129-18134, 2004.

${ }^{124}$ Radisky, D. C. Epithelial-mesenchymal transition. J. Cell Sci. 118:4325-4326, 2005.

${ }^{125}$ Rafii, S., and D. Lyden. Therapeutic stem and progenitor cell transplantation for organ vascularization and regeneration. Nat. Med. 9:702-712, 2003

${ }^{126}$ Rafii, S., M. C. Oz, J. A. Seldomridge, B. Ferris, A. S. Asch, R. L. Nachman, F. Shapiro, E. A. Rose, and H. R. Levin. Characterization of hematopoietic cells arising on the textured surface of left ventricular assist devices. Ann. Thorac. Surg. 60:1627$1632,1995$.

${ }^{127}$ Rahimtoola, S. H. Choice of prosthetic heart valve for adult patients. J. Am. Coll. Cardiol. 41:893-904, 2003.

${ }^{128}$ Rahimtoola, S. H. The next generation of prosthetic heart valves needs a proven track record of patient outcomes at $>$ or $=15$ to 20 years. J. Am. Coll. Cardiol. 42:1720-1721, 2003.

${ }^{129}$ Ramamurthi, A., and I. Vesely. Evaluation of the matrixsynthesis potential of crosslinked hyaluronan gels for tissue engineering of aortic heart valves. Biomaterials 26:999-1010, 2005.

${ }^{130}$ Ratner, B. D., and S. J. Bryant. Biomaterials: Where we have been and where we are going. Ann. Rev. Biomed. Eng. 6:41-75, 2004.

${ }^{131}$ Rieder, E., G. Seebacher, M. Kasimir, E. Eichmair, B. Winter, B. Dekan, E. Wolner, P. Simon, and G. Weigel. Tissue engineering of heart valves: decellularized porcine and human valve scaffolds differ importantly in residual potential to attract monocytic cells. Circulation 111:2792-2797, 2005.

${ }^{132}$ Robinson, K. A., J. Li, M. Mathison, A. Redkar, J. Cui, N. A. Chronos, R. G. Matheny, and S. F. Badylak. Extracellular matrix scaffold for cardiac repair. Circulation 112:I135-I143, 2005.

${ }^{133}$ Roeder, R. A., G. C. Lantz, and L. A. Geddes. Mechanical remodeling of small-intestine submucosa small-diameter vascular grafts-A preliminary report. Biomed. Instrum. Technol. 35:110-120, 2001.

${ }^{134}$ Ross, J. J., and R. T. Tranquillo. ECM gene expression correlates with in vitro tissue growth and development in fibrin gel remodeled by neonatal smooth muscle cells. Matrix Biol. 22:477-490, 2003.

${ }^{135}$ Rossig, L., C. Urbich, and S. Dimmeler. Endothelial progenitor cells at work. Not mature yet, but already stress-resistant. Arterioscler. Thromb. Vasc. Biol. 24:1977-1979. 
${ }^{136}$ Roy, R., U. M. Wewer, D. Zurakowski, S. E. Pories, and M. A. Moses. ADAM 12 cleaves extracellular matrix proteins and correlates with cancer status and stage. J. Biol. Chem. 279:5132351330, 2004.

${ }^{137}$ Saiura, A., M. Sata, Y. Hirata, R. Nagai, and M. Makuuchi. Circulating smooth muscle progenitor cells contribute to atherosclerosis. Nat. Med. 7:382-383, 2001.

${ }^{138}$ Sata, M., Fukuda, D., Tanaka, K., Kaneda, Y., Yashiro, H., and I. Shirakawa. The role of circulating precursors in vascular repair and lesion formation. J. Cell Mol. Med. 9:557-568, 2005.

${ }^{139}$ Sata, M., A. Saiura, A. Kunisato, A. Tojo, S. Okada, T. Tokuhisa, H. Hirai, M. Makuuchi, Y. Hirata, and R. Nagai. Hematopoietic stem cells differentiate into vascular cells that participate in the pathogenesis of atherosclerosis. Nat. Med. 8:403-409, 2002.

${ }^{140}$ Sayk, F., I. Bos, U. Schubert, T. Wedel, and H. H. Sievers. Histopathologic findings in a novel decellularized pulmonary homograft: an autopsy study. Ann. Thorac. Surg. 79:17551758, 2005.

${ }^{141}$ Schenke-Layland, K., I. Riemann, F. Opitz, K. Konig, K. J. Halbhuber, and U. A. Stock. Comparative study of cellular and extracellular matrix composition of native and tissue engineered heart valves. Matrix Biol. 23:113-125, 2004.

${ }^{142}$ Schmitt-Graff, A., A. Desmouliere, and G. Gabbiani. Heterogeneity of myofibroblast phenotypic features: an example of fibroblastic cell plasticity. Virchows Arch. 425:3-24, 1994.

${ }^{143}$ Schoen, F. J. Aortic valve structure-function correlations: role of elastic fibers no longer a stretch of the imagination. J. Heart Valve Dis. 6:1-6, 1997.

${ }^{144}$ Schoen, F. J., S. H. Goodenough, M. I. Ionescu, and N. S. Braunwald. Implications of late morphology of BraunwaldCutter mitral heart valve prostheses. J. Thorac. Cardiovasc. Surg. 88:208-216, 1984.

${ }^{145}$ Schoen, F. J. Future directions in tissue heart valves: Impact of recent insights from biology and pathology. J. Heart Valve Dis. 8:350-358, 1999.

${ }^{146}$ Schoen, F. J. Pathology of heart valve substitution with mechanical and tissue prostheses. In: Cardiovascular Pathology 3rd Ed., edited by M. D. Silver, A. I. Gotlieb, and F. J. Schoen. New York: Churchill Livingstone, 2001, pp. 629-677.

${ }^{147}$ Schoen, F. J., and W. D. Edwards. Valvular heart disease: General principles and stenosis. In: Cardiovascular Pathology 3rd Ed., edited by M. D. Silver, A. I. Gotlieb, and F. J. Schoen. New York: Churchill Livingstone, 2001, pp. 402-405.

${ }^{148}$ Schurch, W., T. A. Seemayer, and G. Gabbiani. The myofibroblast: a quarter century after its discovery. Am. J. Surg. Pathol. 22:141-147, 1998.

${ }^{149}$ Shi, Q., S. Rafii, M. H. Wu, E. S. Wijelath, C. Yu, A. Ishida, Y. Fujita, S. Kothari, R. Mohle, L. R. Sauvage, M. A. Moore, R. F. Storb, and W. P. Hammond. Evidence for circulating bone marrow-derived endothelial cells. Blood 92:362-367, 1998.

${ }^{150}$ Shi, Y., A. Ramamurthi, and I. Vesely. Towards tissue engineering of a composite aortic valve. Biomed. Sci. Instrum . 38:35-40, 2002.

${ }^{151}$ Shi, Y., and I. Vesely. Fabrication of mitral valve chordae by directed collagen gel shrinkage. Tissue Eng. 9:1233-1242, 2003.

${ }^{152}$ Shinoka, T., C. K. Breuer, R. E. Tanel, G. Zund, T. Miura, P. X. Ma, R. Langer, J. P. Vacanti, and J. E. Mayer. Tissue engineering heart valves: valve leaflet replacement study in a lamb model. Ann. Thorac. Surg. 60:S513-S516, 1995.

${ }^{153}$ Shinoka, T., P. X. Ma, D. Shum-Tim, C. K. Breuer, R. A. Cusick, G. Zund, R. Langer, J. P. Vacanti, and J. E. Mayer. Tissue-engineered heart valves. Autologous valve leaflet replacement study in a lamb model. Circulation 94:II164-II168, 1996.
${ }^{154}$ Silva, G. A., C. Czeisler, K. L. Niece, E. Beniash, D. A. Harrington, J. A. Kessler, and S. I. Stupp. Selective differentiation of neural progenitor cells by high-epitope density nanofibers. Science 303:1352-1355, 2004.

${ }^{155}$ Simmons, C. A., G. R. Grant, E. Manduchi, and P. F. Davies. Spatial heterogeneity of endothelial phenotypes correlates with side-specific vulnerability to calcification in normal porcine aortic valves. Circ. Res. 96:792-799, 2005.

${ }^{156}$ Simon, P., M. T. Kasimir, G. Seebacher, G. Weigel, R. Ullrich, U. Salzer-Muhar, E. Rieder, and E. Wolner. Early failure of the tissue engineered porcine heart valve SYNERGRAFT in pediatric patients. Eur. J. Cardiothorac. Surg. 23:1002-1006, 2003.

${ }^{157}$ Simper, D., P. G. Stalboerger, C. J. Panetta, S. Wang, and N. M. Caplice. Smooth muscle progenitor cells in human blood. Circulation 106:1199-1204, 2002.

${ }^{158}$ Sodian, R., T. Lemke, C. Fritsche, S. P. Hoerstrup, P. Fu, E. V. Potapov, H. Hausmann, and R. Hetzer. Tissue-engineering bioreactors: a new combined cell-seeding and perfusion system for vascular tissue engineering. Tissue Eng. 8:863-870, 2002.

${ }^{159}$ Spina, M., F. Ortolani, A. E. Messlemani, A. Gandaglia, J. Bujan, N. Garcia-Honduvilla, I. Vesely, G. Gerosa, D. Casarotto, L. Petrelli, and M. Marchini. Isolation of intact aortic valve scaffolds for heart-valve bioprostheses: extracellular matrix structure, prevention from calcification, and cell repopulation features. J. Biomed. Mater. Res. 67:1338-1350, 2003.

${ }^{160}$ Srivastava, D., and E. N. Olson. A genetic blueprint for cardiac development. Nature 407:221-226, 2000.

${ }^{161}$ Stegemann, J. P., and R. M. Nerem. Phenotype modulation in vascular tissue engineering using biochemical and mechanical stimulation. Ann. Biomed. Eng. 31:391-402, 2003.

${ }^{162}$ Steinhoff, G., U. Stock, N. Karim, H. Mertsching, A. Timke, R. Meliss, K. Pethig, A. Haverich, and A. Bader. Tissue engineering of pulmonary heart valves on allogenic acellular matrix conduits in vivo restoration of valve tissue. Circulation 102:III50-III-55, 2000.

${ }^{163}$ Stock, U. A., and K. Schenke-Layland. Performance of decellularized xenogeneic tissue in heart valve replacement. Biomaterials 27:1-2, 2006.

${ }^{164}$ Sutherland, F. W. H., T. E. Perry, Y. Yu, M. C. Sherwood, E. Rabkin, Y. Masuda, G. A. Garcia, D. L. McLellan, G. C. Engelmayr, M. S. Sacks, F. J. Schoen, and J. E. Mayer. From stem cells to viable autologous semilunar heart valves. Circulation 111:2783-2791, 2005.

${ }^{165}$ Szmitko, P. E., P. W. Fedak, R. D. Weisel, D. J. Stewart, M. J. Kutryk, and S. Verma. Endothelial progenitor cells: new hope for a broken heart. Circulation 107:3093-3100, 2003.

${ }^{166}$ Tamariz, E., and F. Grinnell. Modulation of fibroblast morphology and adhesion during collagen matrix remodeling. Mol. Biol. Cell 13:3915-3929, 2002.

${ }^{167}$ Tanaka, K., M. Sata, D. Fukuda, Y. Suematsu, N. Motomura, S. Takamoto, Y. Hirata, and R. Nagai. Age-associated aortic stenosis in apolipoprotein E-deficient mice. J. Am. Coll. Cardiol. 46:134-141, 2005.

${ }^{168}$ Taylor, P. M., S. P. Allen, and M. H. Yacoub. Phenotypic and functional characterization of interstitial cells from human heart valves, pericardium and skin. J. Heart Valve Dis. 9:150-158, 2000.

${ }^{169}$ Taylor, P. M., P. Batten, N. J. Brand, P. S. Thomas, and M. H. Yacoub. The cardiac valve interstitial cell. Int. J. Biochem. Cell. Biol. 35:113-118, 2003.

${ }^{170}$ Tranquillo, R. T., M. A. Durrani, and A. G. Moon. Tissue engineering science: consequences of cell traction force. $C y$ totechnology 10:225-250, 1992. 
${ }^{171}$ Tranquillo, R., T. Girton, and M. Neidert. Tissue Equivalent Approach to a Tissue Engineered Cardiovascular Valve. Minneapolis: Regents of the University of Minnesota; 2003.

${ }^{172}$ Urbich, C., A. Aicher, C. Heeschen, E. Dernbach, W. K. Hofmann, A. M. Zeiher, and S. Dimmeler. Soluble factors released by endothelial progenitor cells promote migration of endothelial cells and cardiac resident progenitor cells. J. Mol. Cell Cardiol. 39:733-742, 2005.

${ }^{173}$ Urbich, C., and S. Dimmeler. Endothelial progenitor cells: characterization and role in vascular biology. Circ. Res. 95:343-353, 2004.

${ }^{174}$ Van den Hoff, M. J., B. P. Kruithof, A. F. Moorman, R. R. Markwald, and A. Wessels. Formation of myocardium after the initial development of the linear heart tube. Dev. Biol. 240:61-76, 2001.

${ }^{175}$ Van Le, T. S., R. Miller, T. Barder, M. Babjuk, D. M. Potter, and R. H. Getzenberg. Highly specific urine-based marker of bladder cancer. Urology 66:1256-1260, 2005.

${ }^{176}$ Vesely, I. Heart valve tissue engineering. Circ. Res. 97:743755, 2005

${ }^{177}$ Walker, G. A., K. S. Masters, D. N. Shah, K. S. Anseth, and L. A. Leinwand. Valvular myofibroblast activation by transforming growth factor-beta: implications for pathological extracellular matrix remodeling in heart valve disease. Circ. Res. 95:253260, 2004

${ }^{178}$ Weinberg, C. B., and E. Bell. A blood vessel model constructed from collagen and cultured vascular cells. Science 231:397400, 1986.

${ }^{179}$ Weinshilboum, R. Inheritance and drug response. N. Engl. J. Med. 348:529-537, 2003.

${ }^{180}$ Werner, N., S. Kosiol, T. Schiegl, P. Ahlers, K. Walenta, A. Link, M. Bohm, and G. Nickenig. Circulating endothelial progenitor cells and cardiovascular outcomes. N. Engl. J. Med. 353:9991007, 2005.
${ }^{181}$ Williams, C., and T. M. Wick. Perfusion bioreactor for small diameter tissue-engineered arteries. Tissue Eng. 10:930-941, 2004.

${ }^{182}$ Wood, J. D., A. Simmons-Byrd, A. R. Spievack, and S. F. Badylak. Use of a particulate extracellular matrix bioscaffold for treatment of acquired urinary incontinence in dogs. $J$. Am. Vet. Med. Assoc. 226:1095-1097, 2005.

${ }^{183}$ Wu, X., L. Huang, Q. Zhou, Y. Song, A. Li, J. Jin, and B. Cui. Mesenchymal stem cells participating in ex vivo endothelium repair and its effect on vascular smooth muscle cells growth. Int. J. Cardiol. 105:274-282, 2005.

${ }^{184} \mathrm{Wu}$, X., E. Rabkin-Aikawa, K. J. Guleserian, T. E. Perry, Y. Masuda, F. W. Sutherland, F. J. Schoen, J. E. Mayer, and J. Bischoff. Tissue-engineered microvessels on three-dimensional biodegradable scaffolds using human endothelial progenitor cells. Am. J. Physiol. Heart Circ. Physiol. 287:H480-H487, 2004.

${ }^{185}$ Yacoub, M. H., and L. H. Cohn. Novel approaches to cardiac valve repair: from structure to function: Part I. Circulation 109:942-950, 2004

${ }^{186}$ Yang, J., M. Yamato, C. Kohno, A. Nishimoto, H. Sekine, F. Fukai, and T. Okano. Cell sheet engineering: recreating tissues without biodegradable scaffolds. Biomaterials 26:64156422, 2005.

${ }^{187}$ Ye, Q., G. Zund, P. Benedikt, S. Jockenhoevel, S. P. Hoerstrup, S. Sakyama, J. A. Hubbell, and M. Turina. Fibrin gel as a three dimensional matrix in cardiovascular tissue engineering. Eur. J. Cardiothorac. Surg. 17:587-591, 2000.

${ }^{188}$ Zund, G., C. K. Breuer, T. Shinoka, P. X. Ma, R. Langer, J. E. Mayer, and J. P. Vacanti. The in vitro construction of a tissue engineered bioprosthetic heart valve. Eur. J. Cardiothorac. Surg. 11:493-497, 1997. 